\section{Questión}

Periodismo / Comunicación ISSN 1669-6581
- Av. $44 \mathrm{~N}^{\circ} 676,1^{\circ}$ piso

CP 1900 - La Plata - Argentina

www.perio.unlp.edu.ar/question

Taller de Arte Silvia Porta - "Desde Casa: lo que nos provoca la pandemia"

Silvia Porta

DOI: https://doi.org/10.24215/16696581e320

\title{
Taller de Arte Silvia Porta - "Desde Casa: Lo que nos provoca la pandemia"
}

\section{Silvia Porta Art Workshop - "From Home: What Causes The Pandemic"}

Presentamos "Desde Casa: Lo que nos provoca la pandemia", muestra colectiva con la participación de 26 artistas. Compartimos además el intercambio de audios entre artistas y maestra, que dan cuenta del proceso creativo en este contexto tan particular. En esta oportunidad, la consigna fue planteada a distancia: se les propuso que expresen los sentimientos de la cuarentena con los materiales que tenían en sus hogares.

Hace 10 años Silvia Porta armó el Taller de Arte para niños y adolescentes en Villa Elisa (La Plata) En este espacio se han creado obras maravillosas de acuerdo con las propuestas temáticas, que se exhiben en muestras abiertas. Por las tardes, en el Taller pasan horas pensando en los proyectos, los materiales, buscando formas, texturas y colores. También realizan visitas a museos y exposiciones.

\section{Intercambio de audios:}

https://ar.ivoox.com/es/51108712 


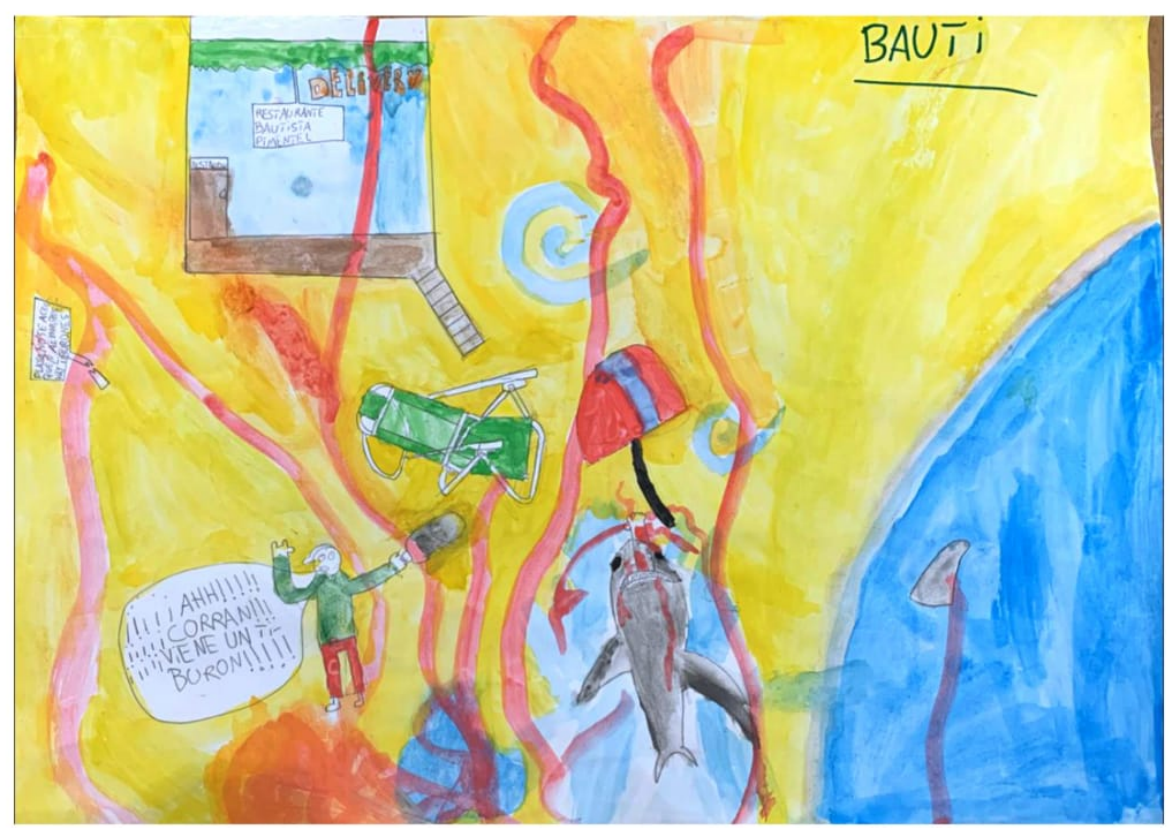

Baucha, "Lejos del mar" 


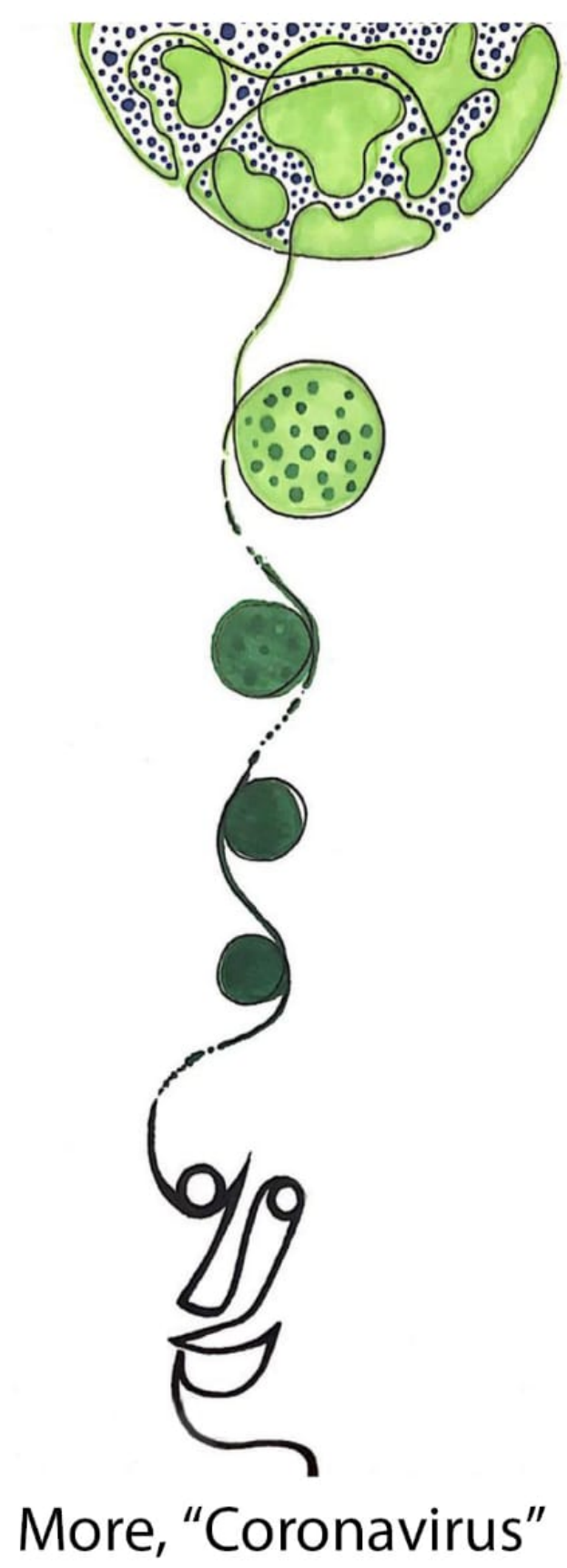




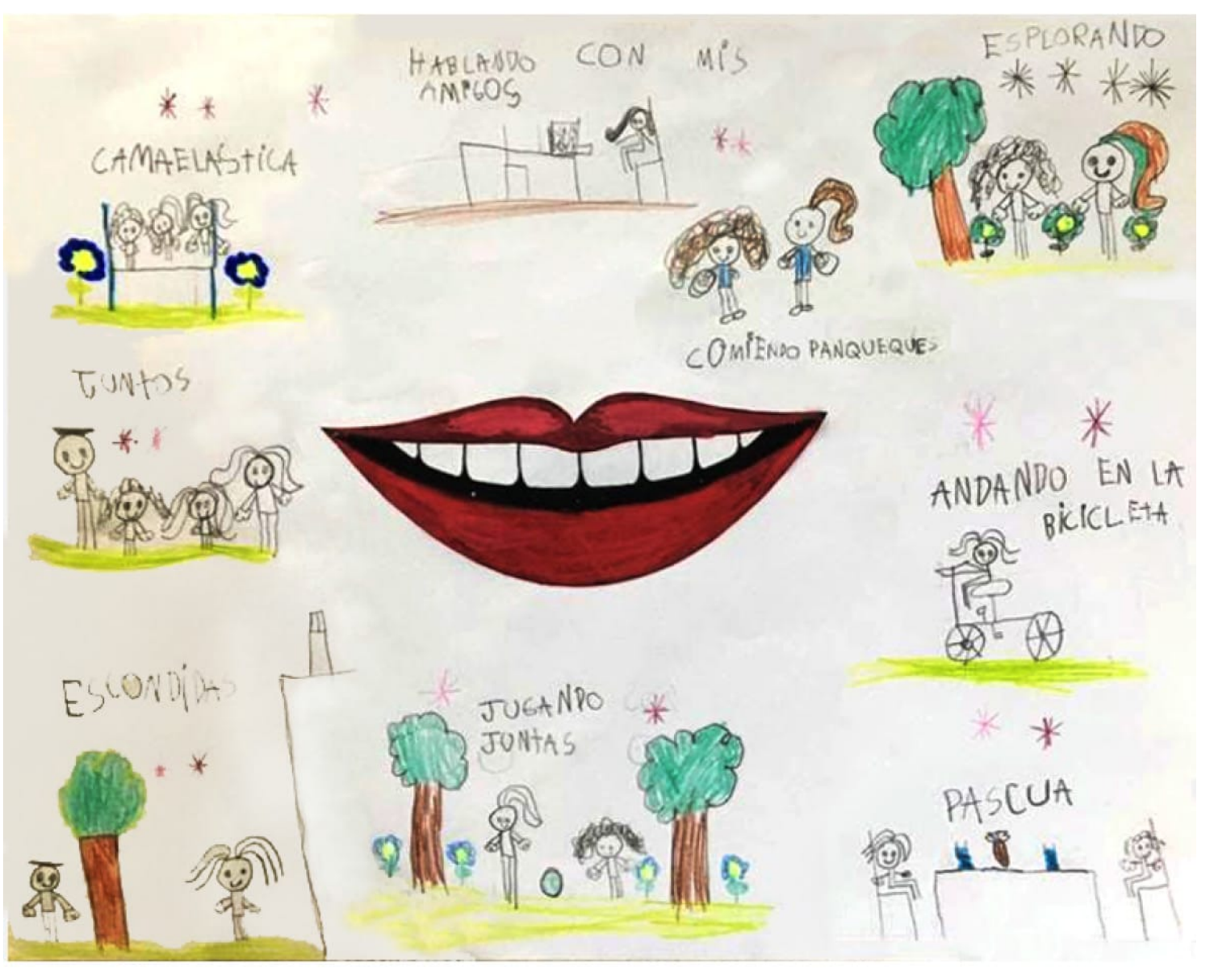

"Algunos días de alegría en cuarentena" 


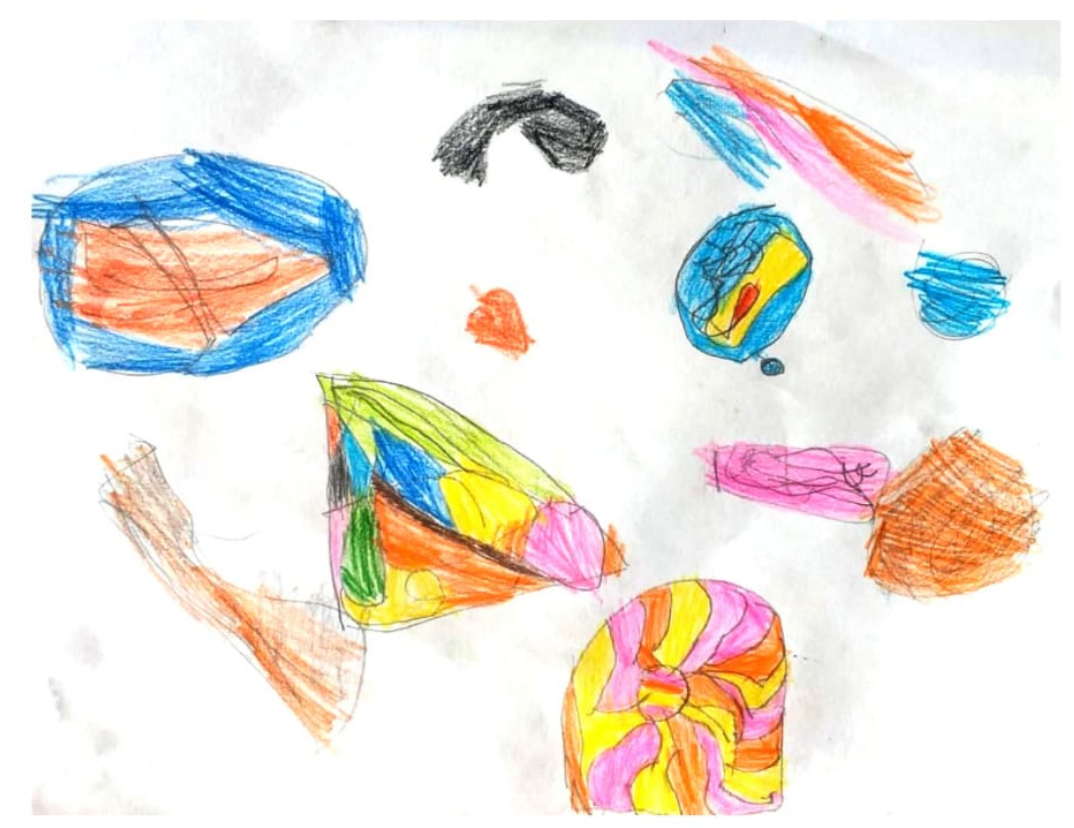

Cata, "La sirena y los peces raros" 


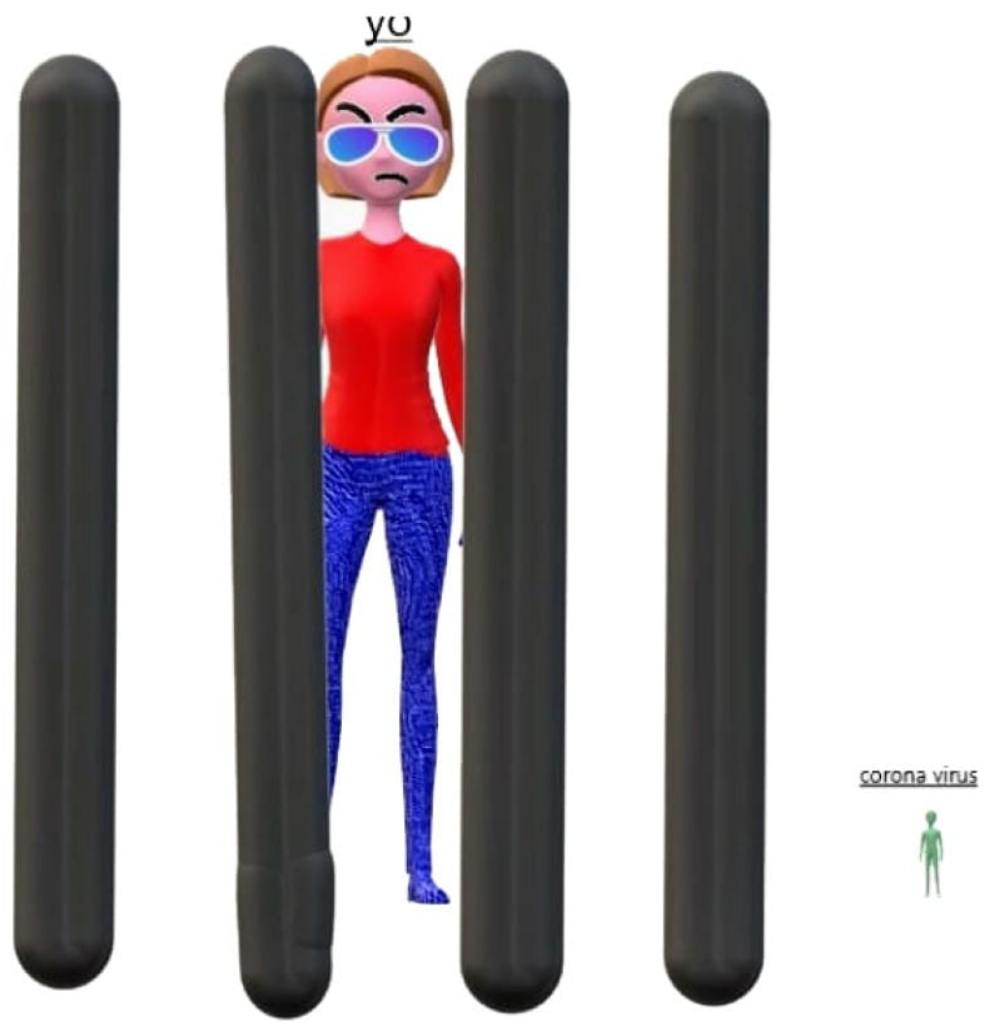

Isabel, "Sin salida" 


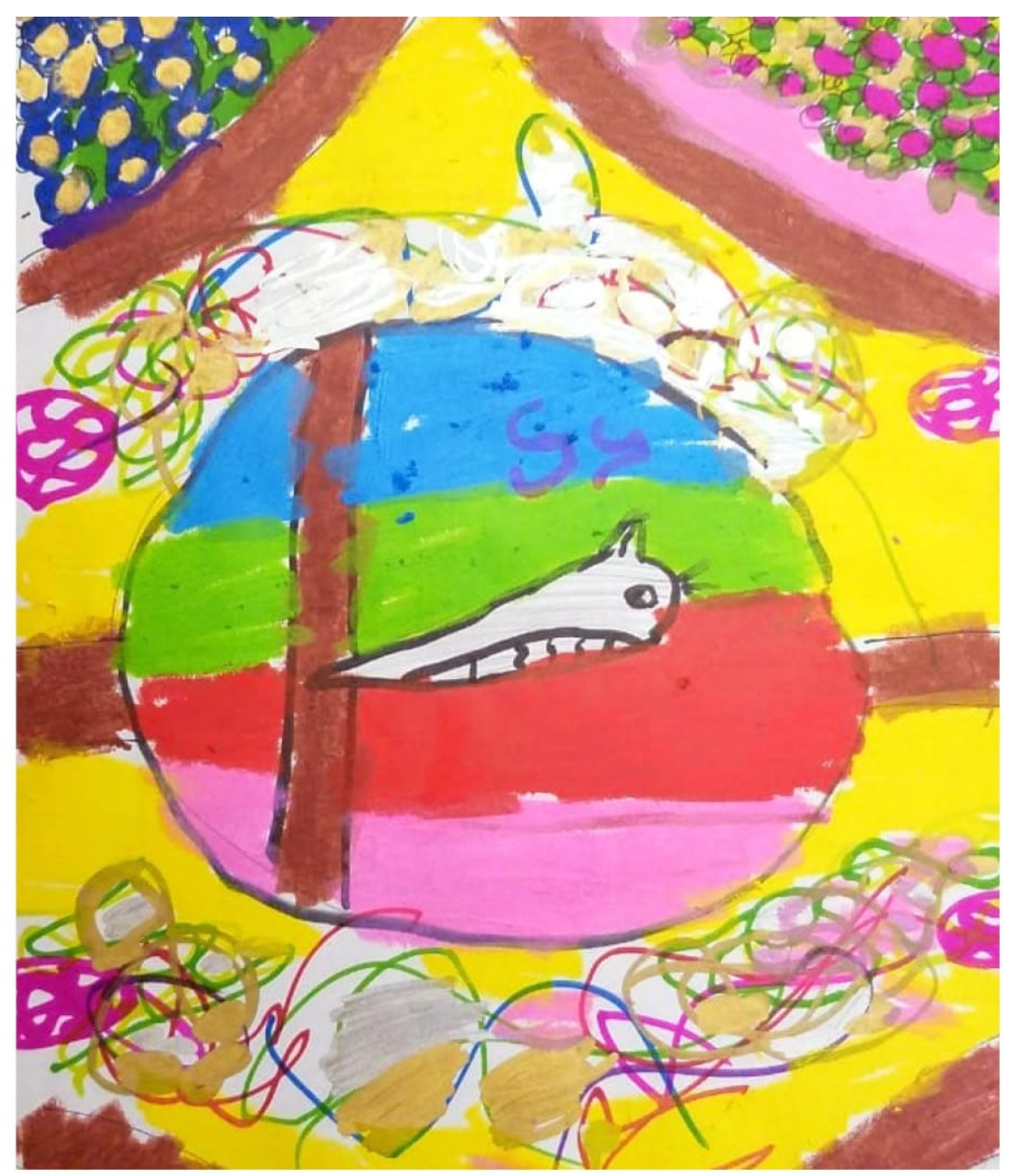

Ofelia, "El mundo de la alegría" 


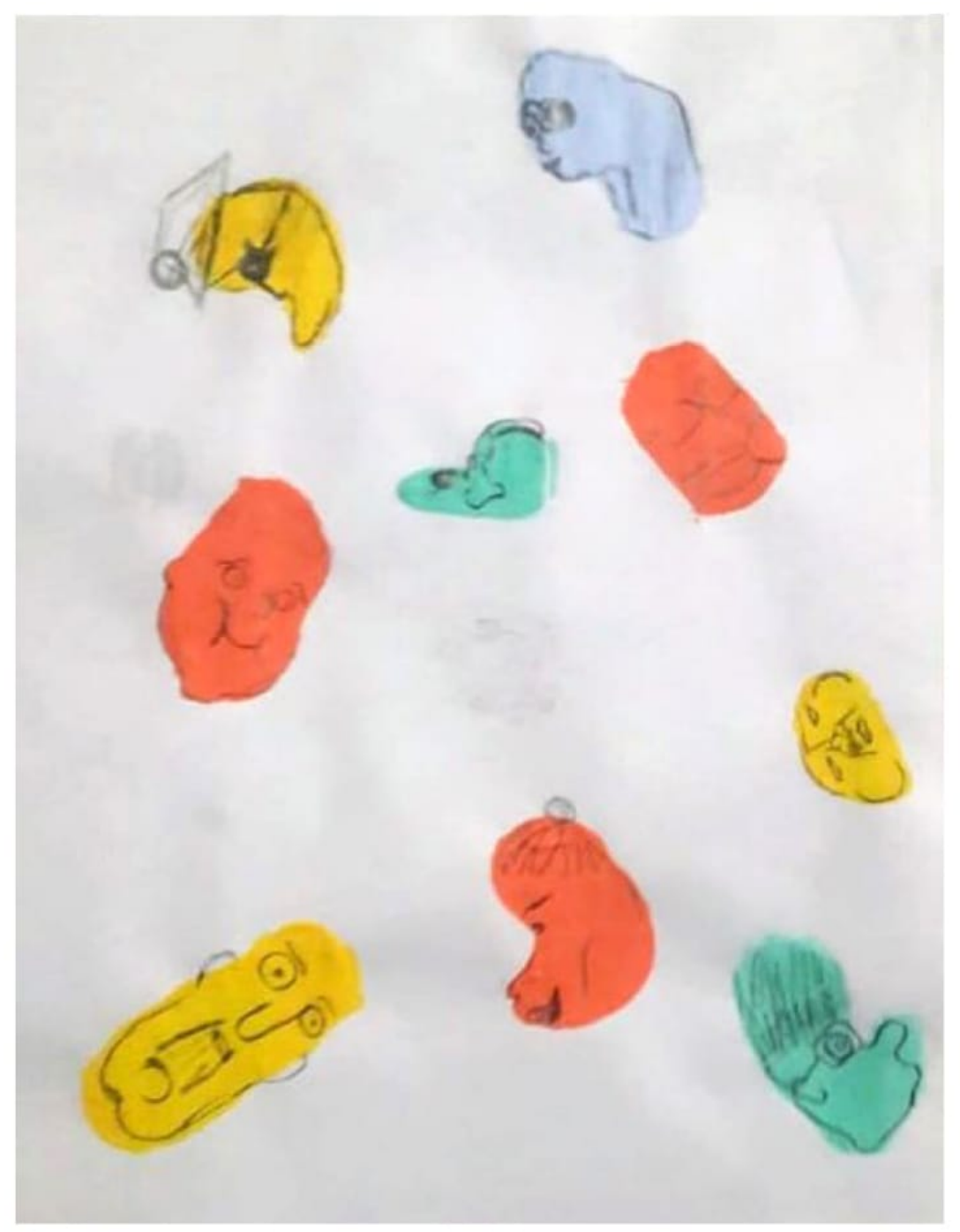

\section{Coco, "Aspectos"}




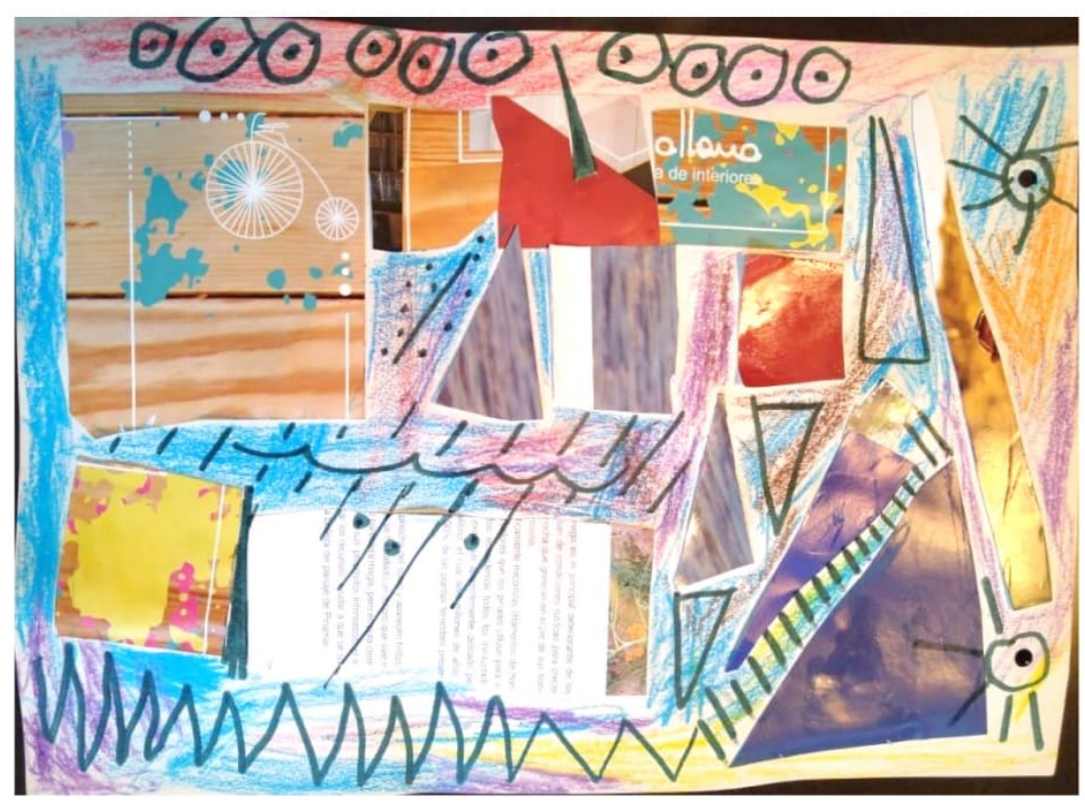

Flora, "Tormenta de verano" 


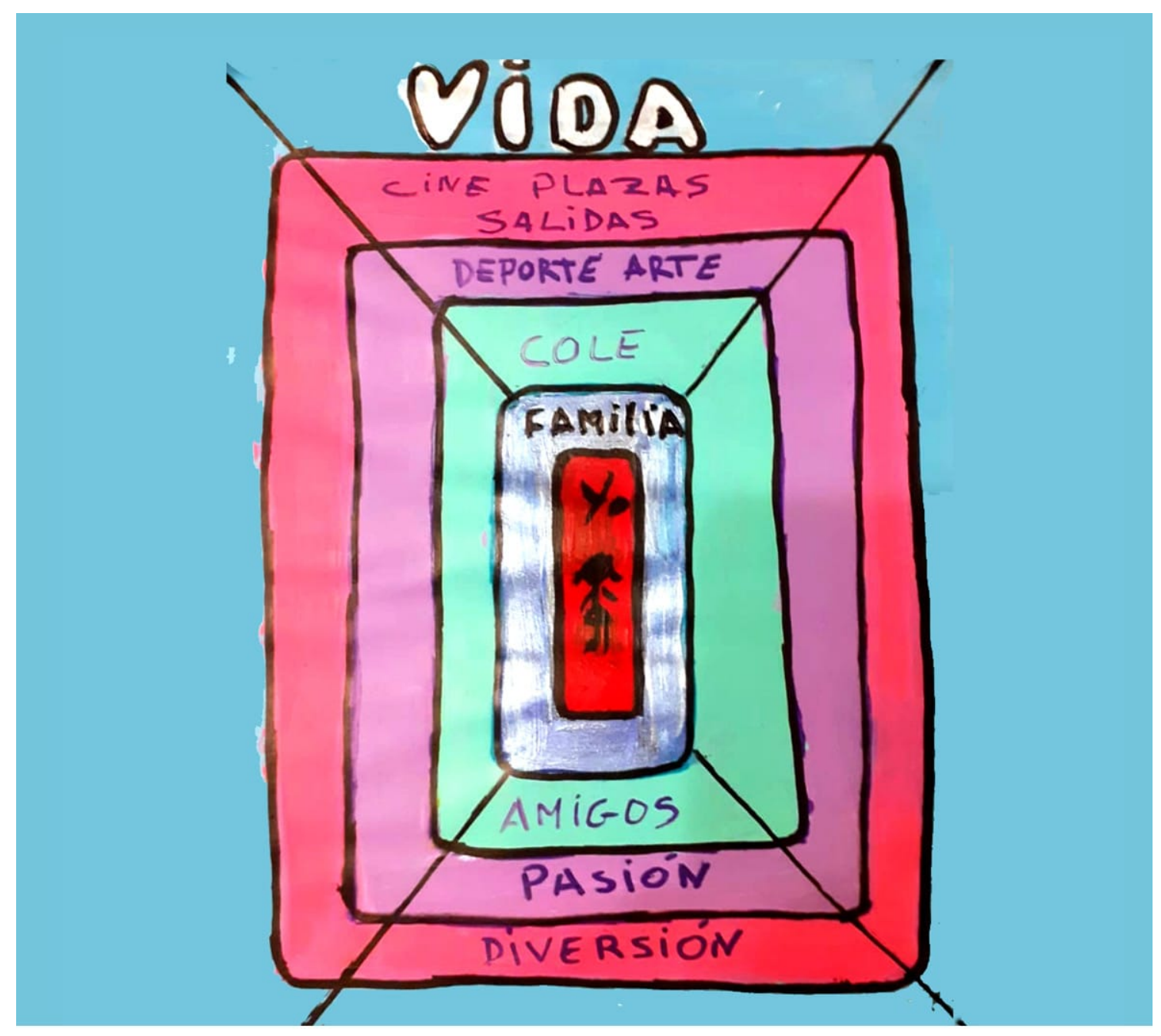

Pupe, "La tristeza de la cuarentena" 


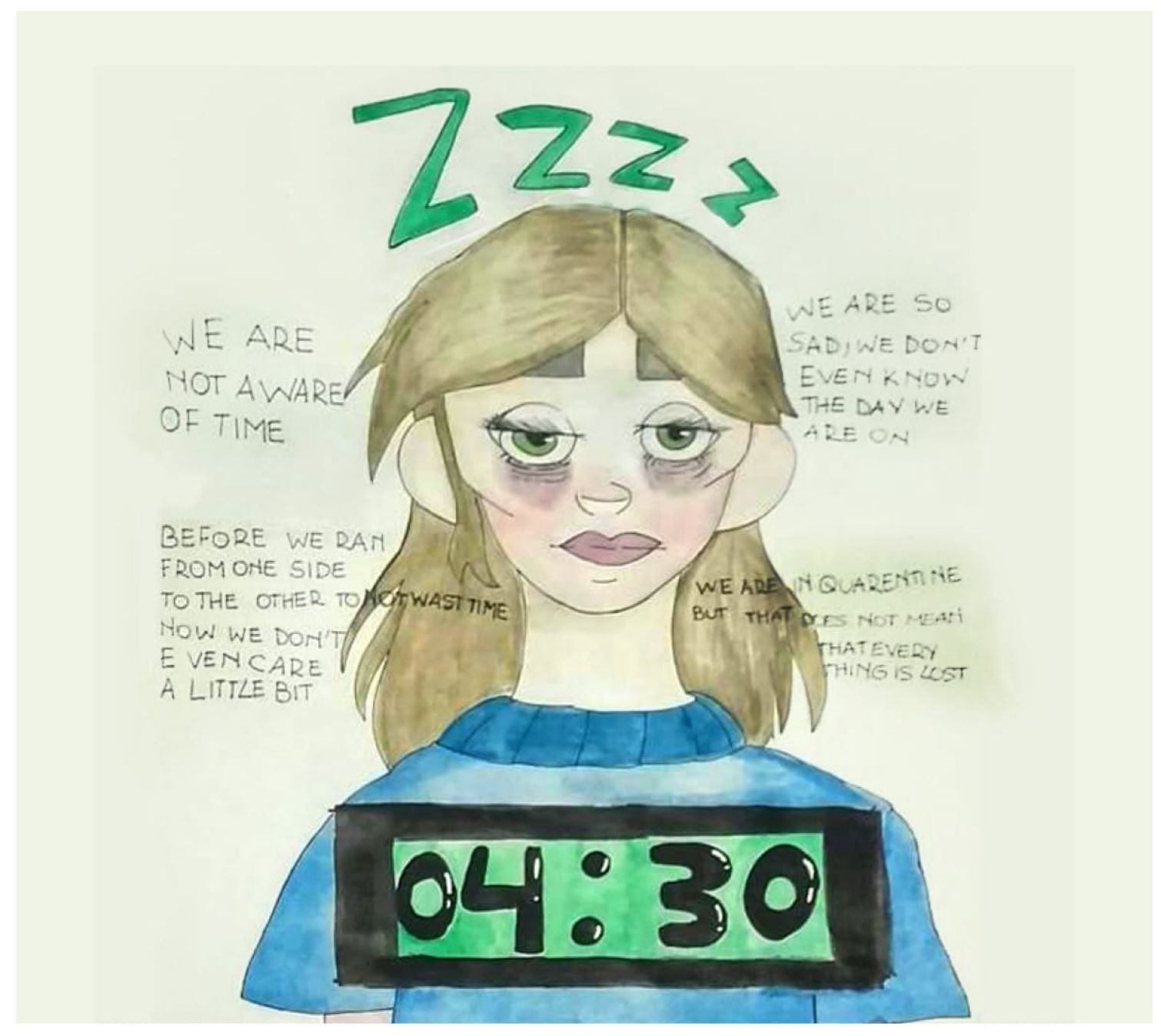

Pili, "El tiempo ya no importa" 


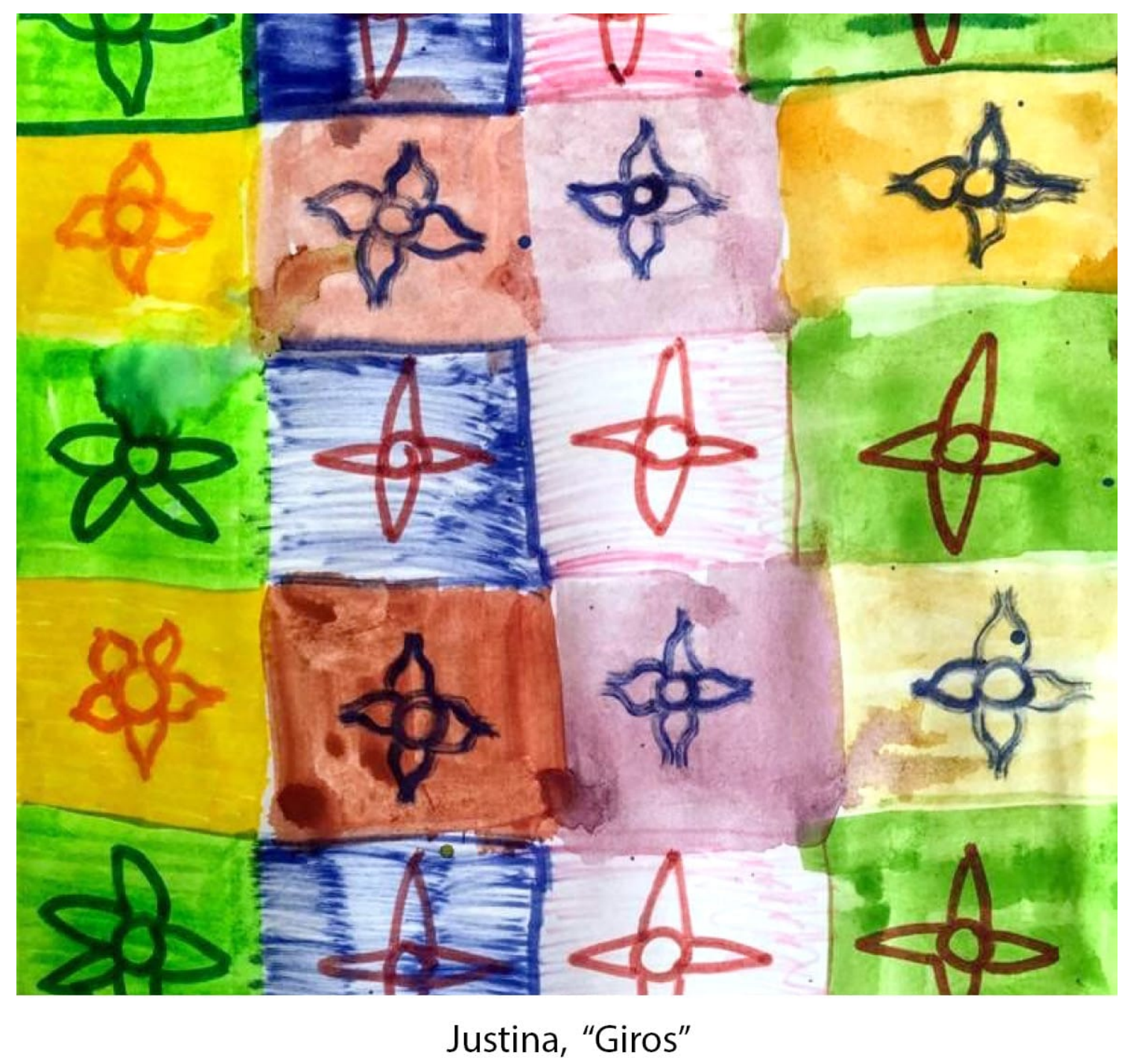




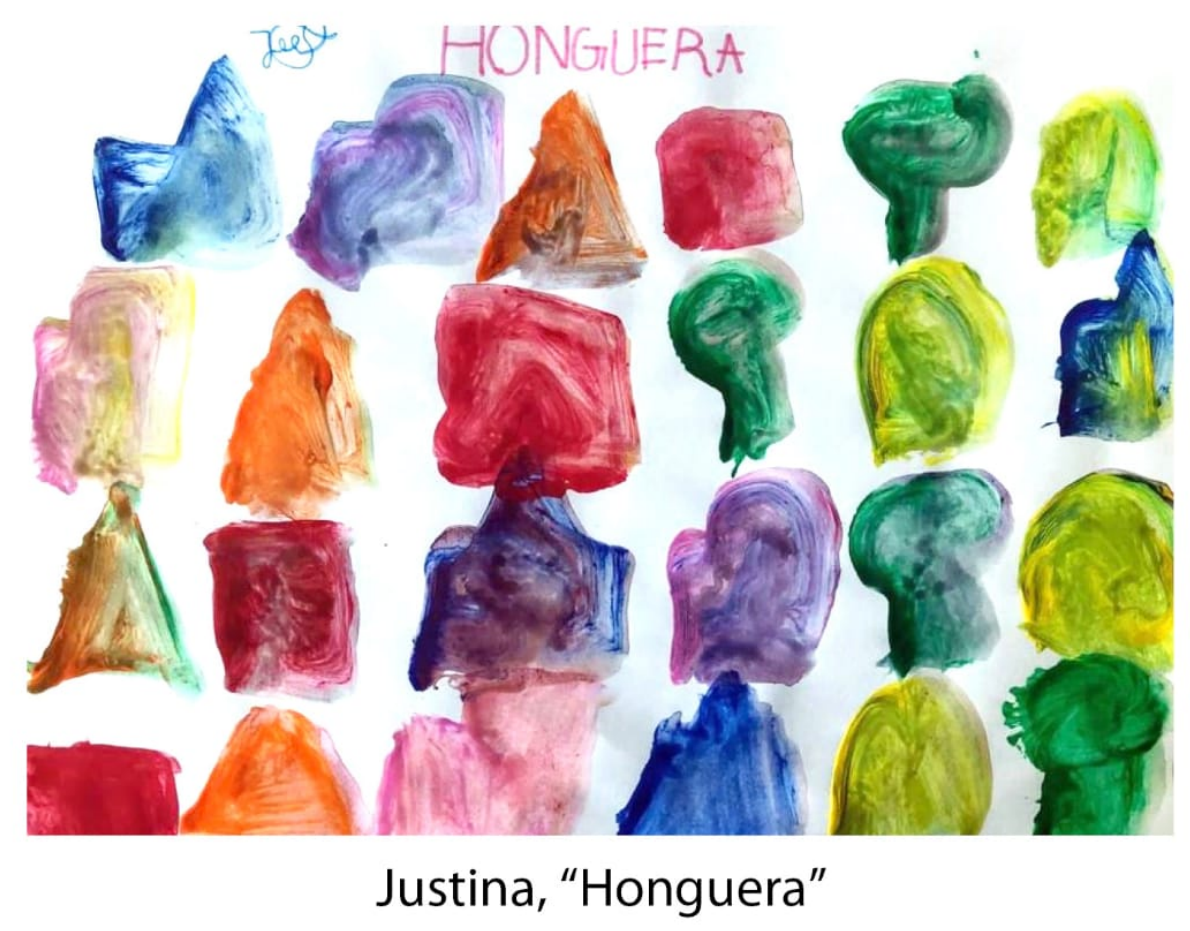




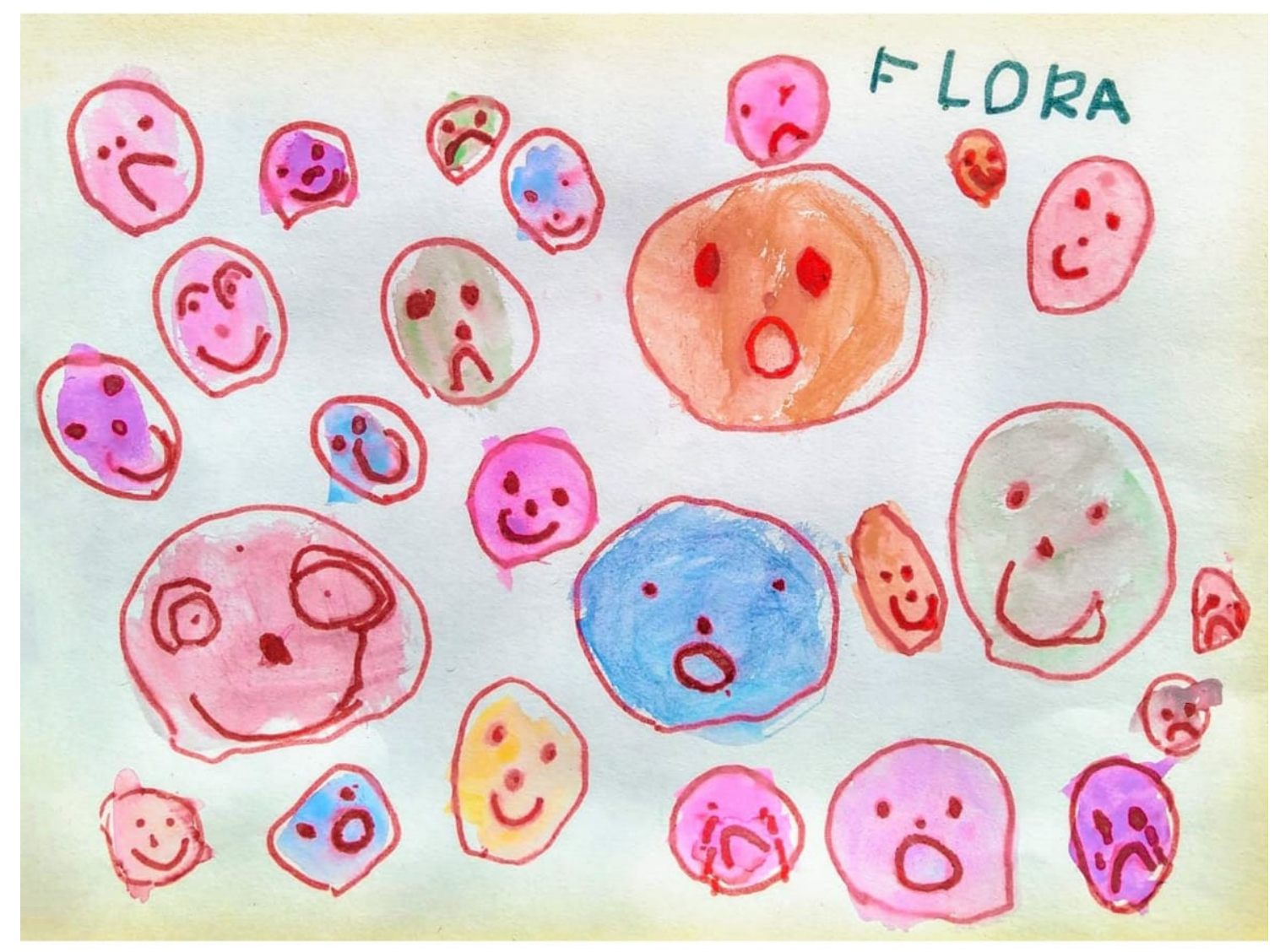

Flora, "Pandemia de estares" 


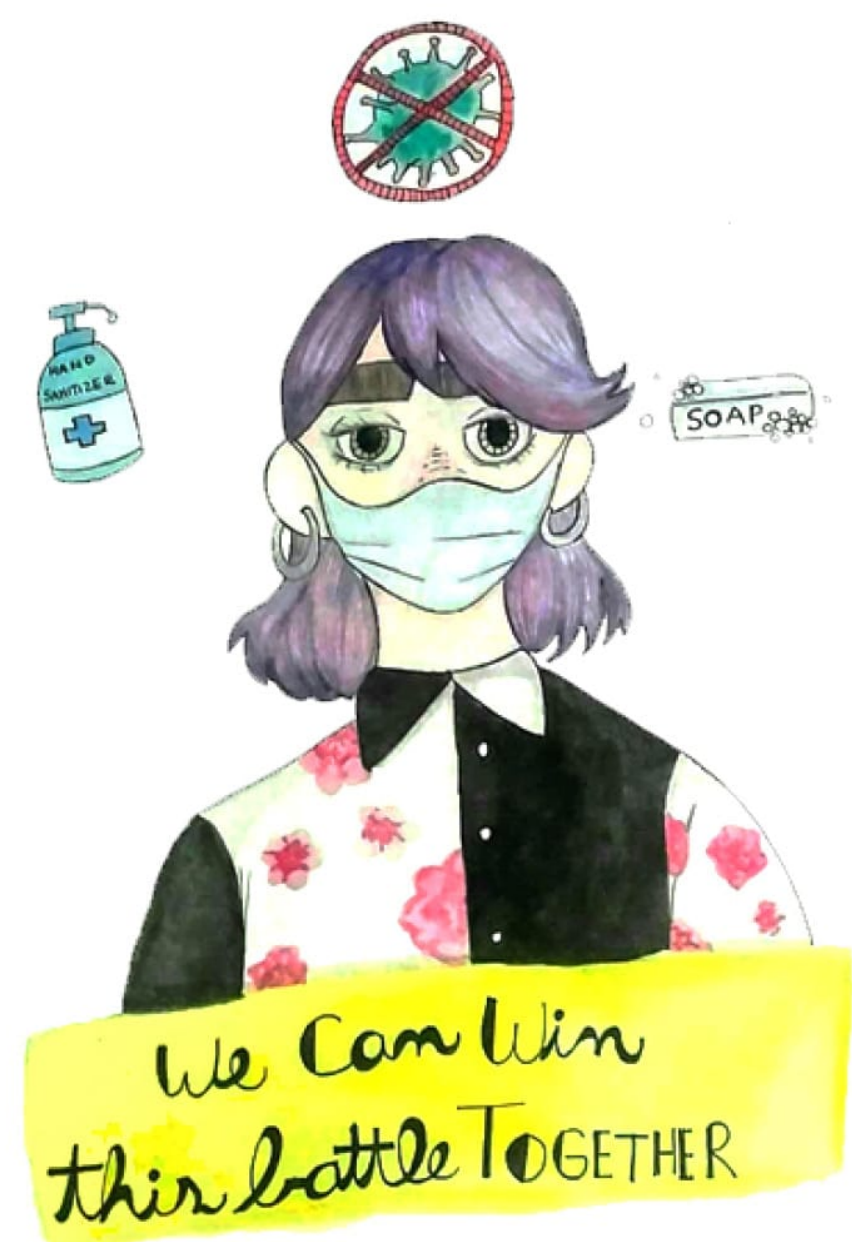

Pili, "Esta batalla se gana entre todos" 


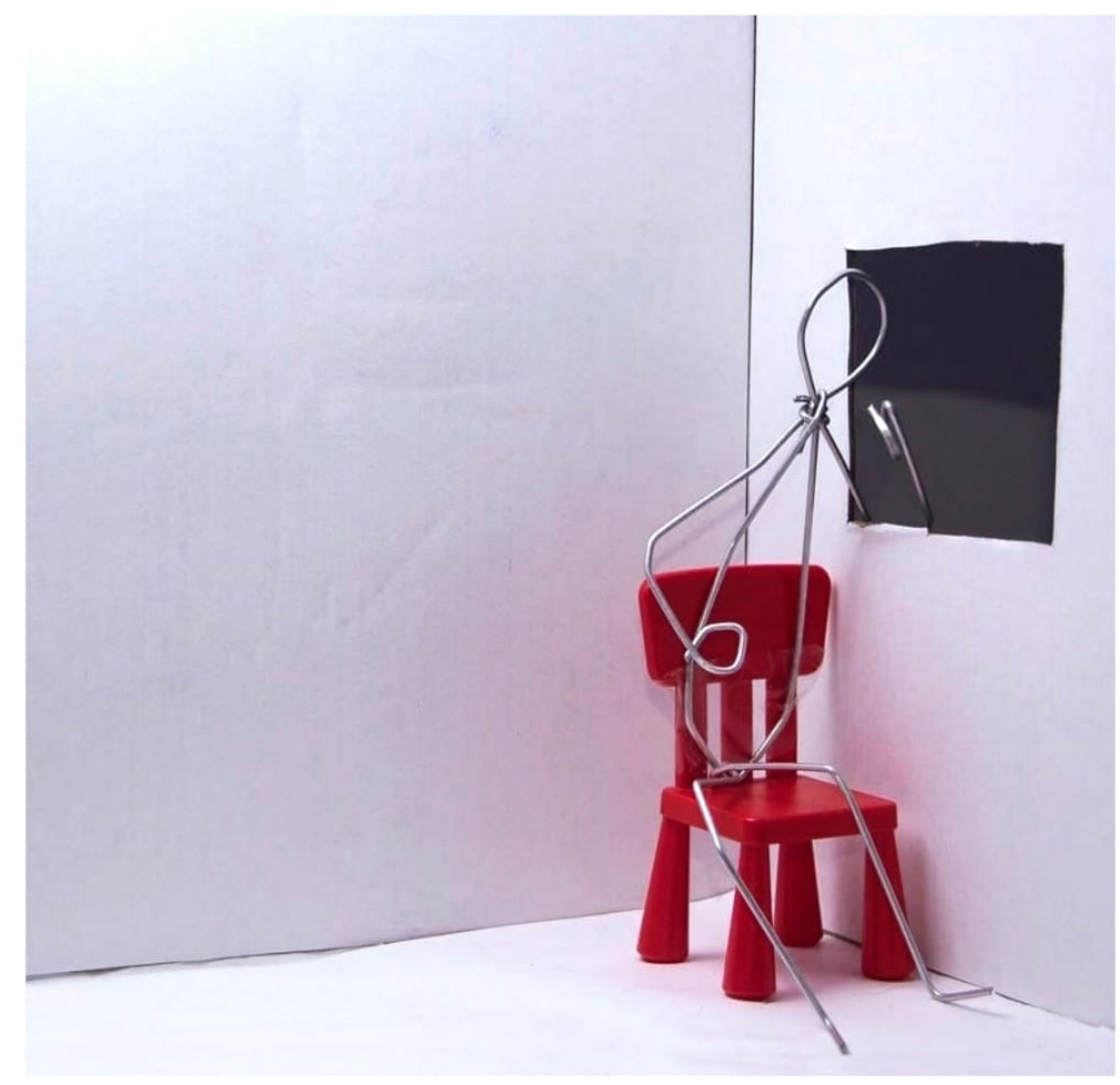

Lucía, "Mente en blanco" 


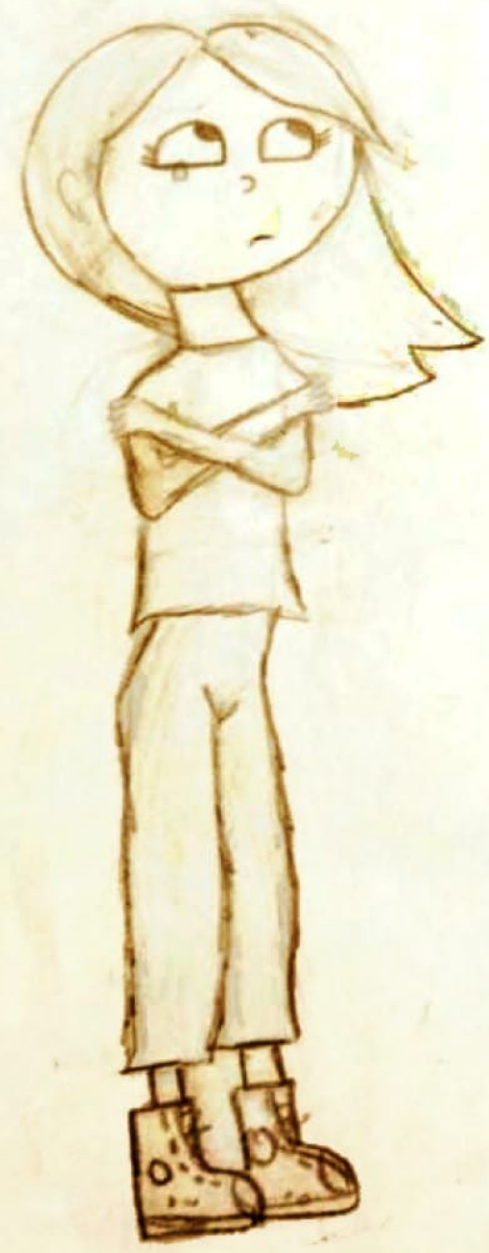

Paula, "Estoy con vos" 


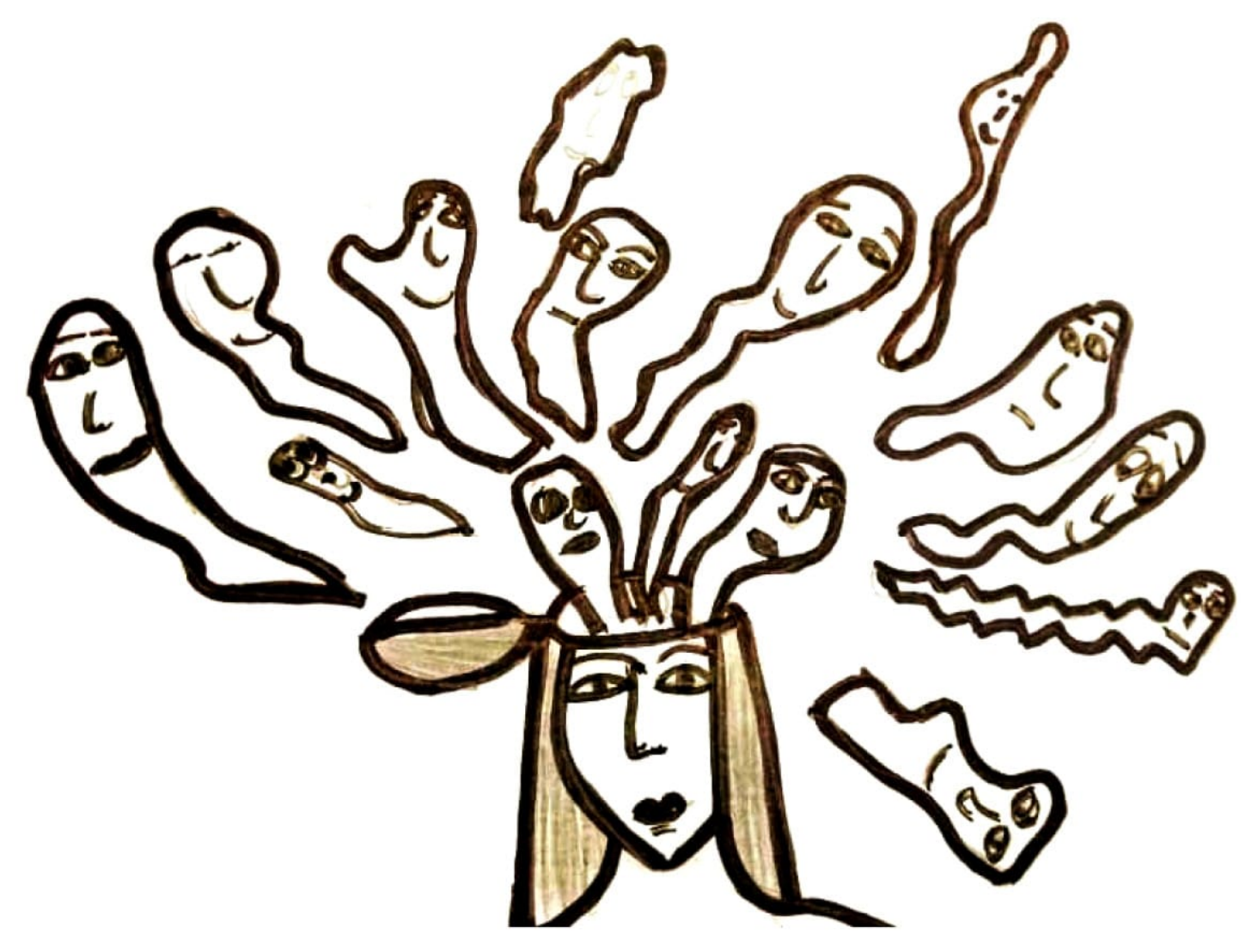

Carme, "Los sentimientos" 


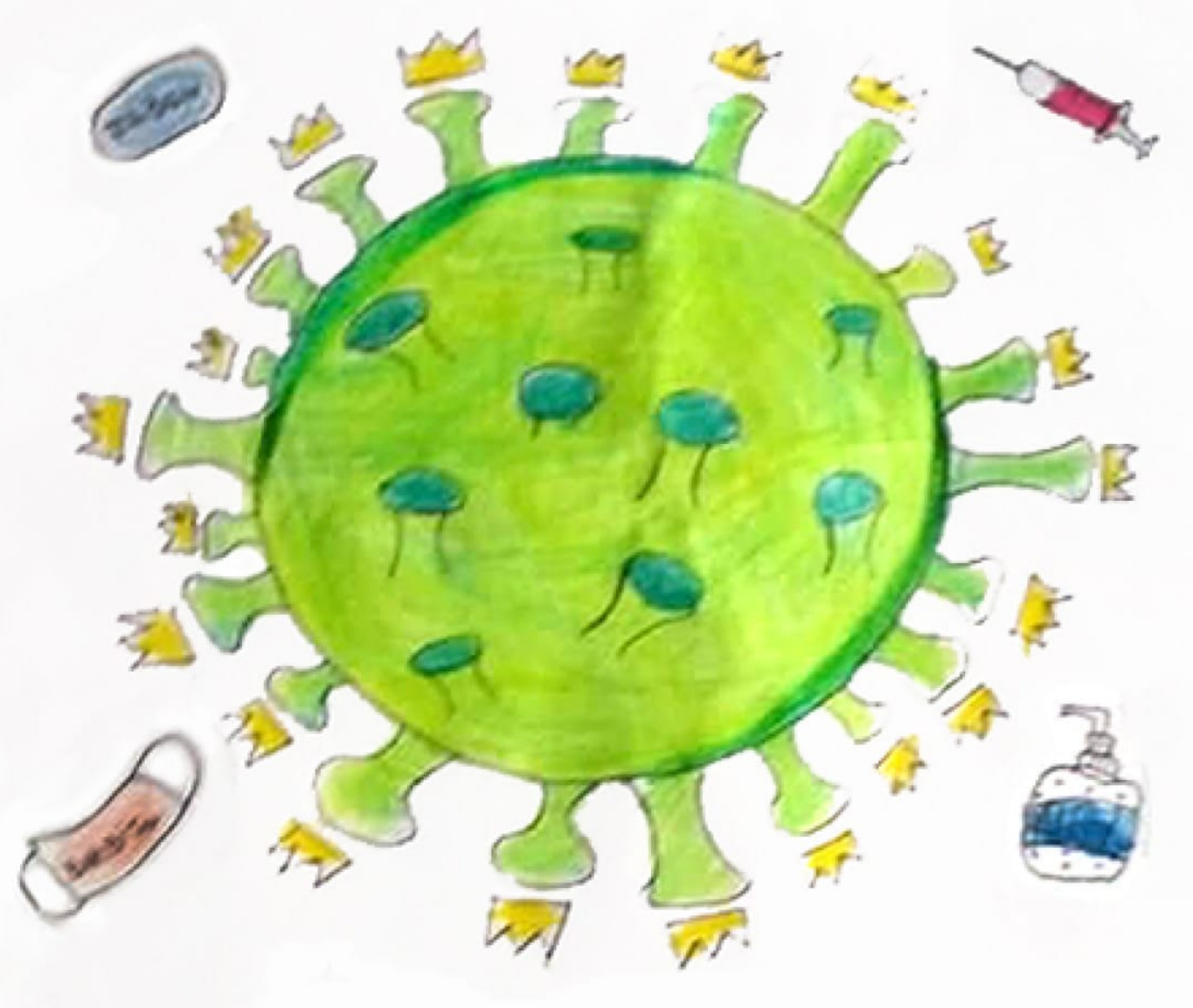

Joaco, "Todos podemos contra el virus" 


\section{(c) $\underset{B Y}{(1)(2)(2)}$}

Esta obra está bajo una Licencia Creative Commons

Atribución-NoComercial-Compartir Igual 4.0 Internacional

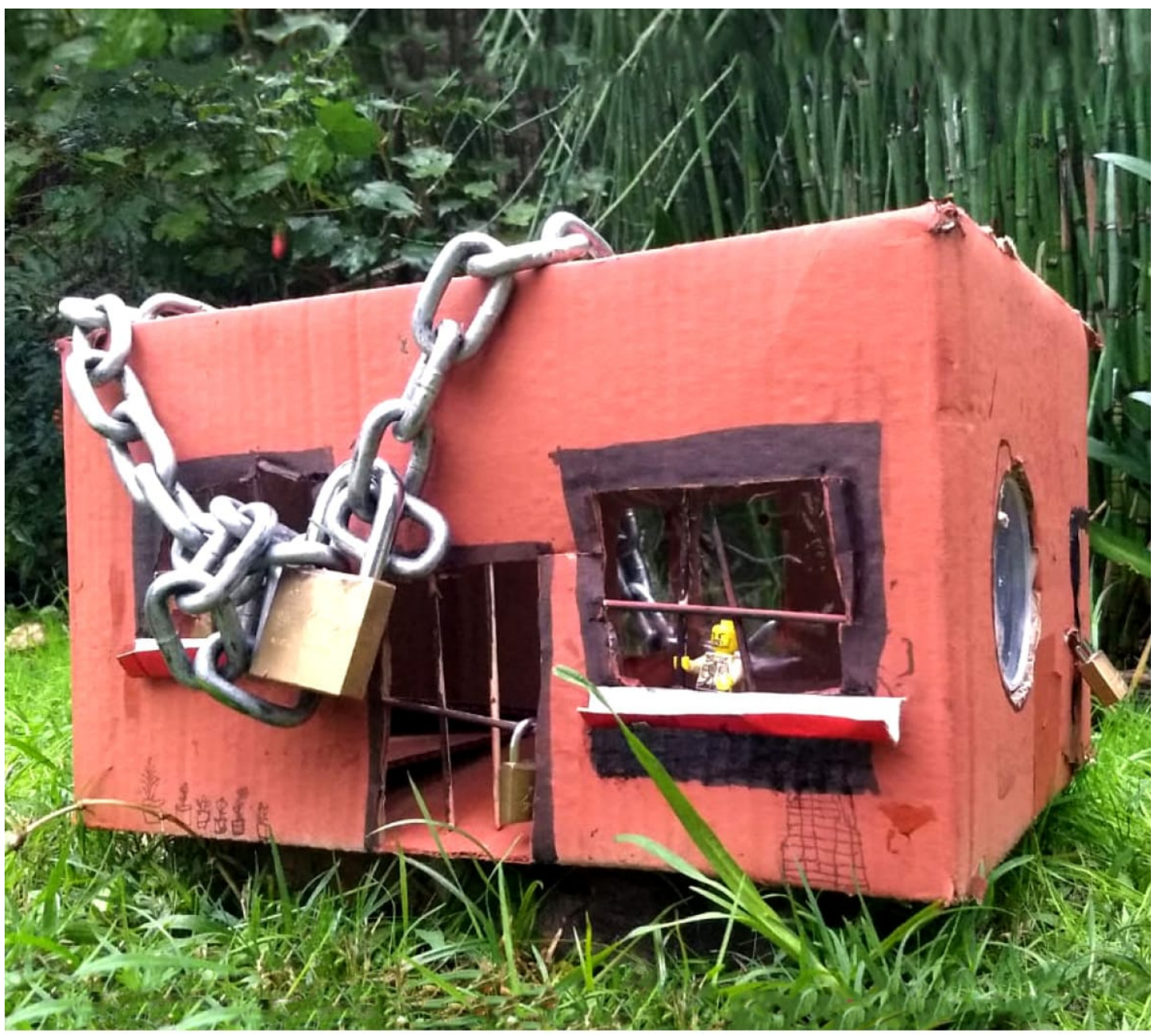

Tomy, "Esto me está volviendo loco” 


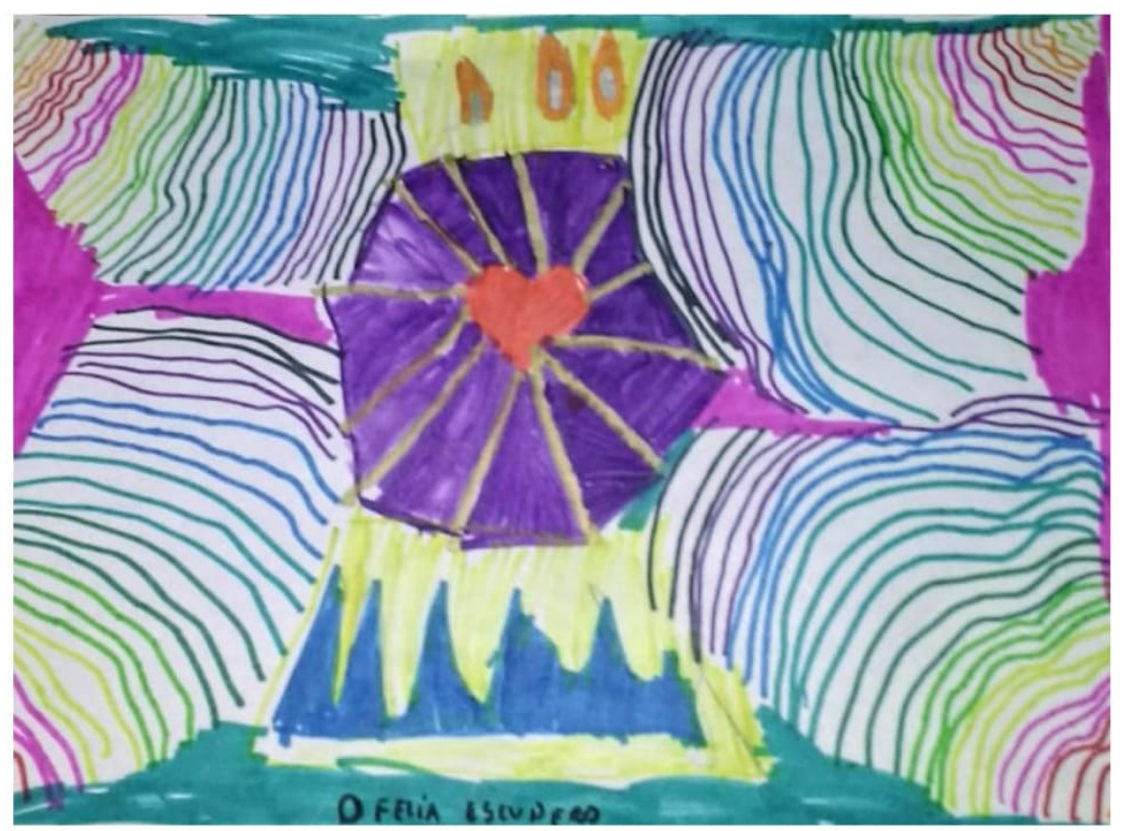

Ofelia, "Corriente de amor" 


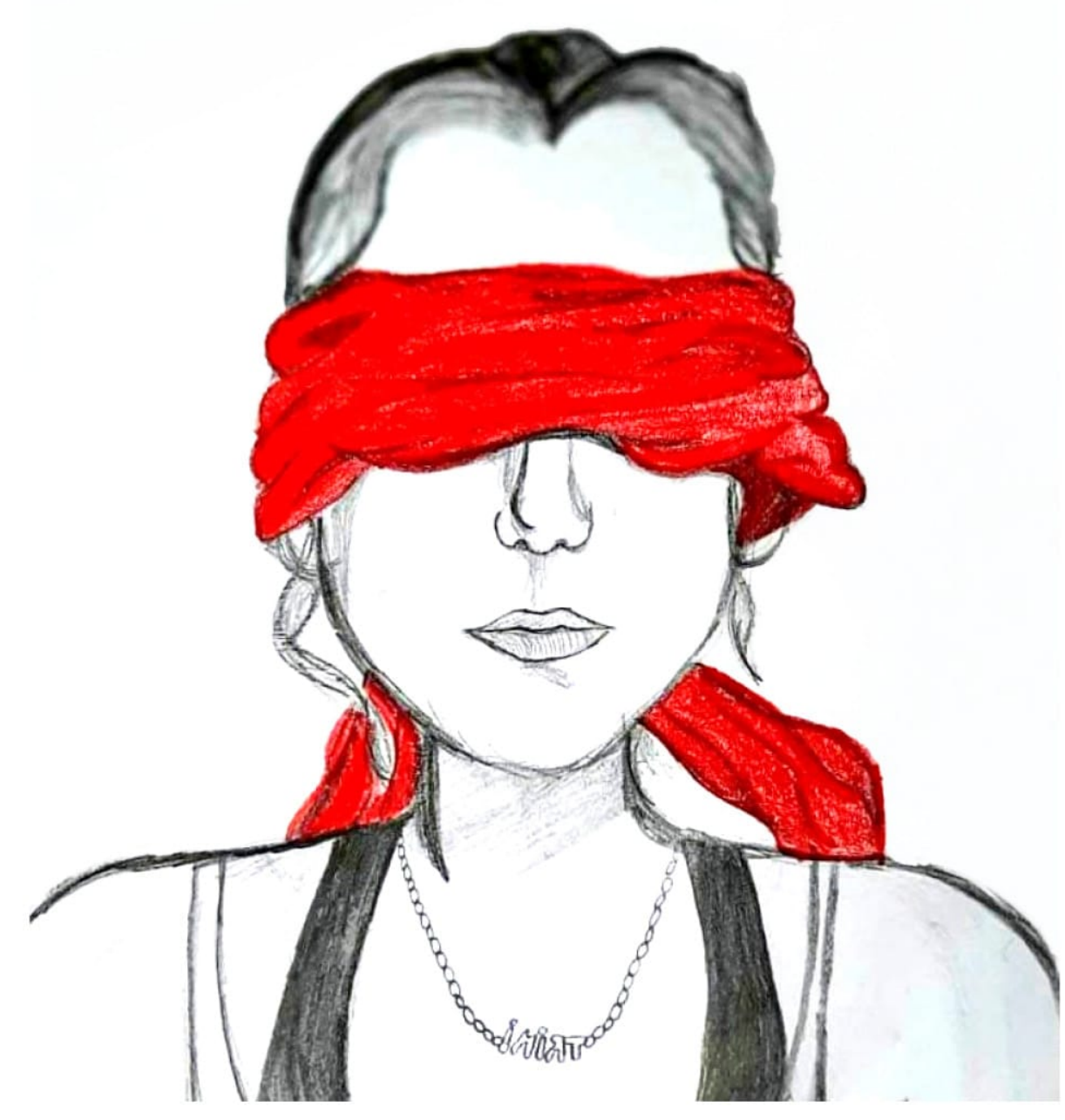

Trini, "La pesadilla despierta” 


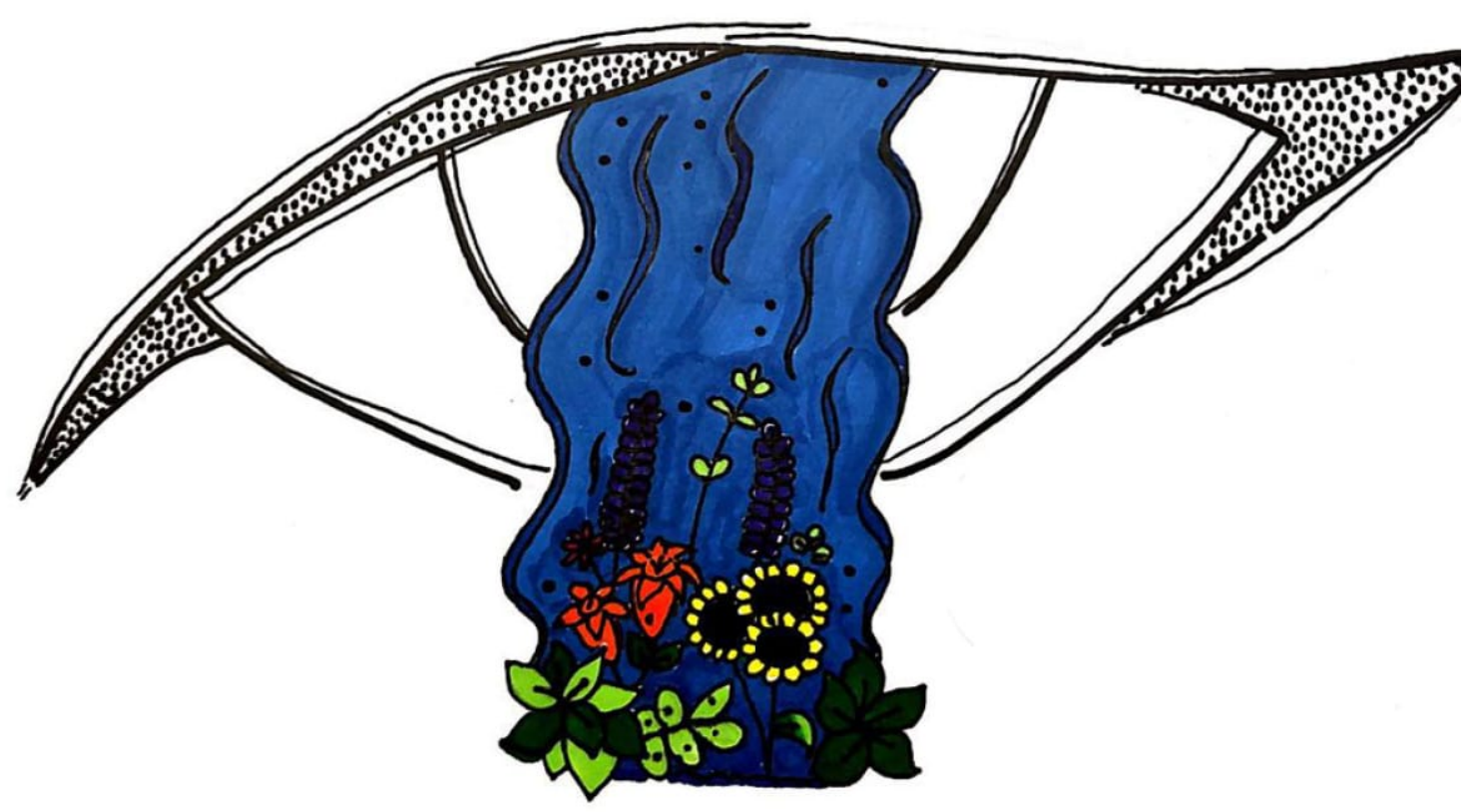

Morena, "Lo que yo veo" 


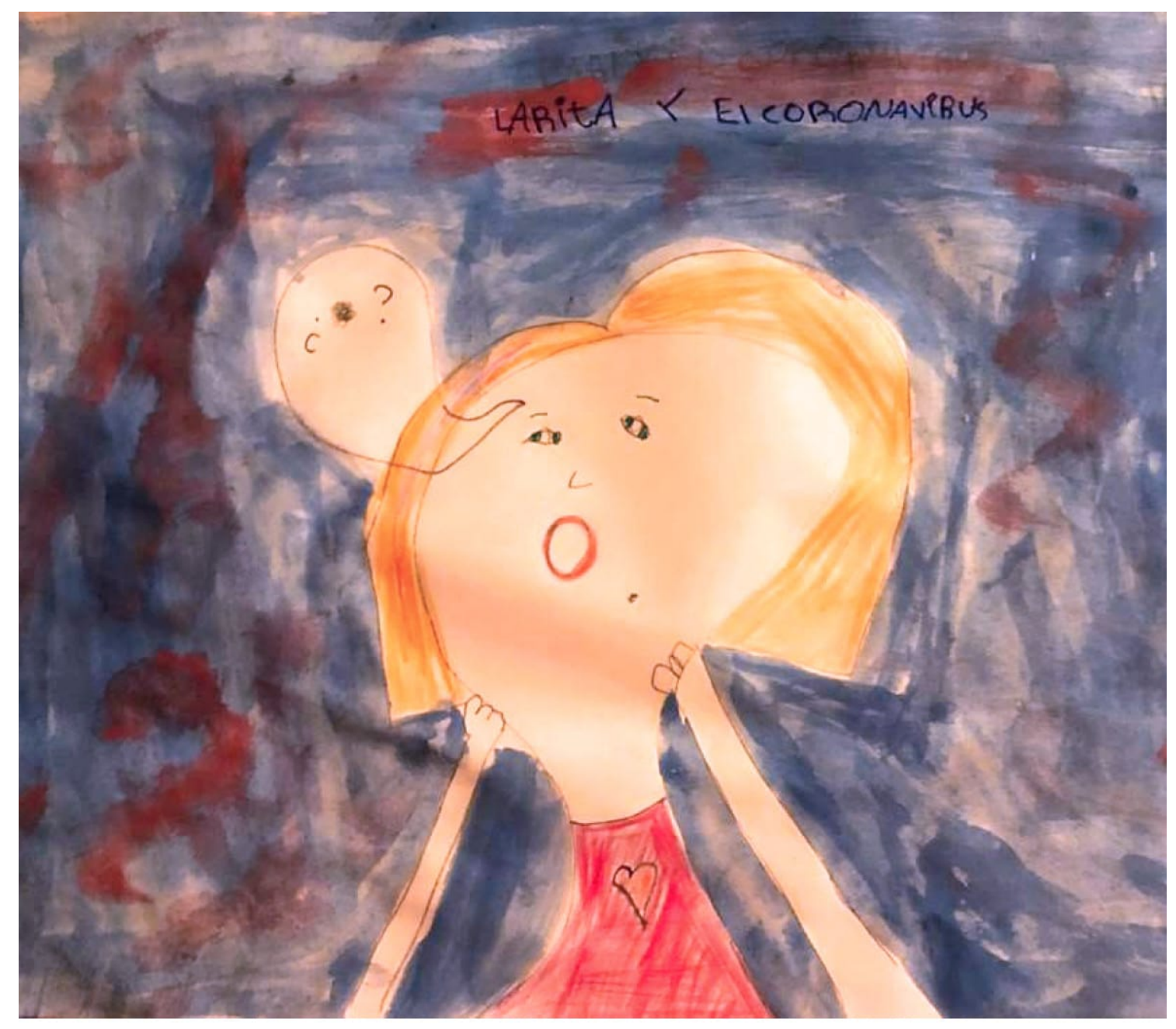

Lara, "Larita y el Coronavirus" 


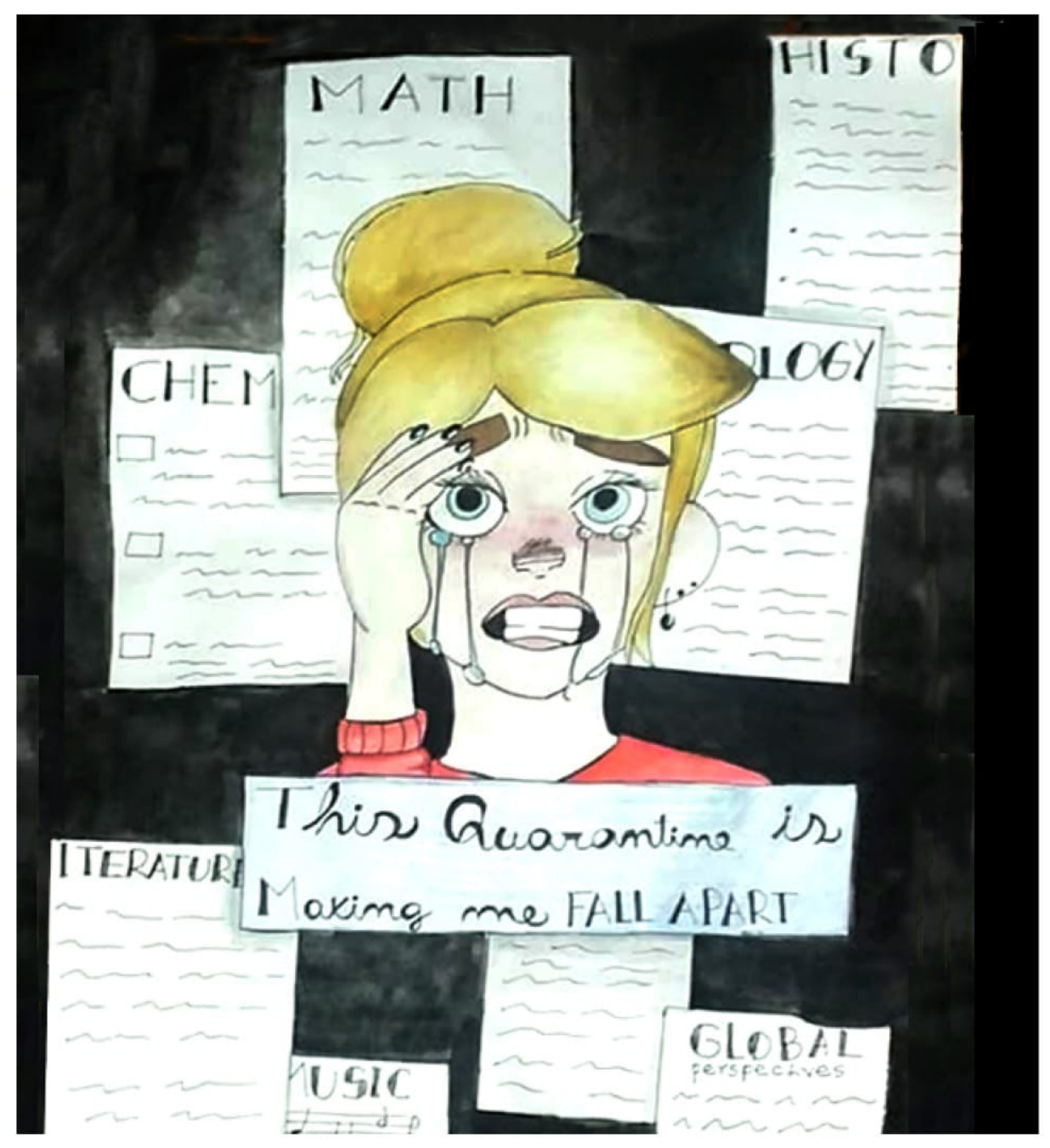

Pili, “Dificultades diarias” 


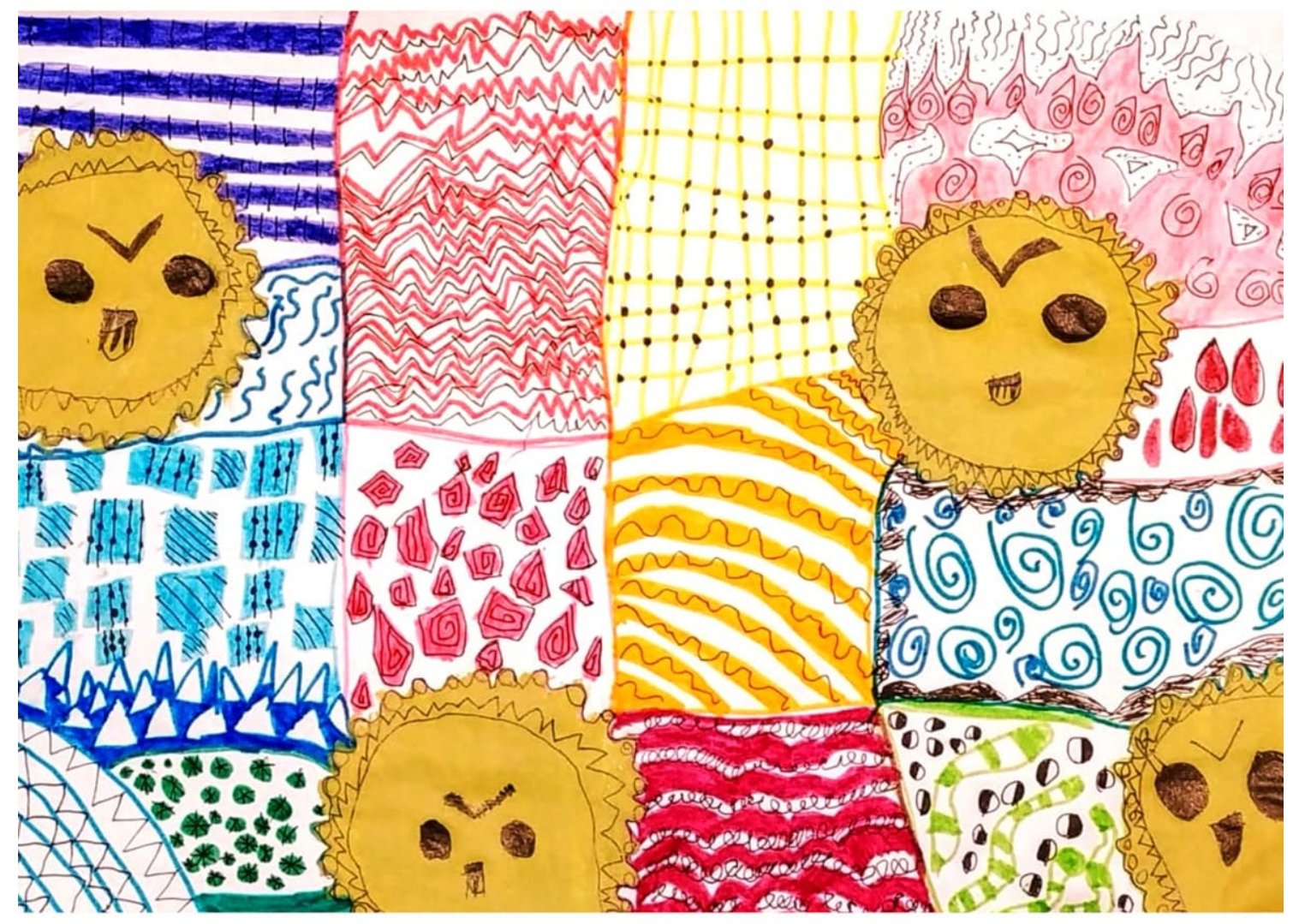

Jojo, "El virus abstracto” 


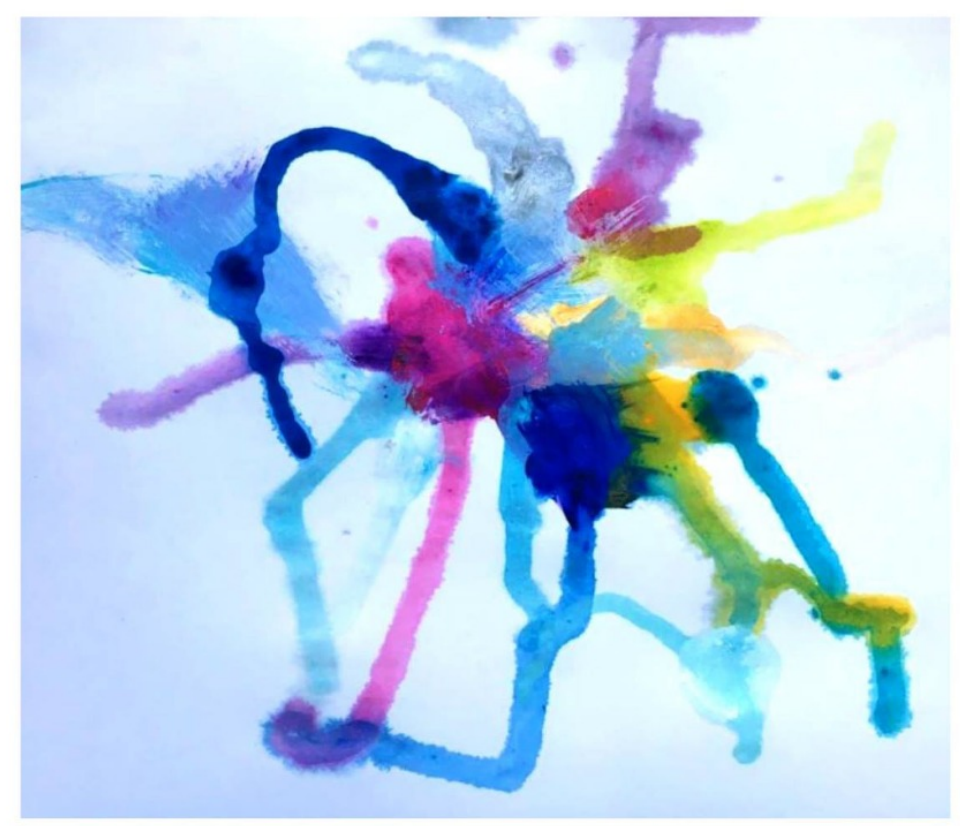

Reni, "El interior" 


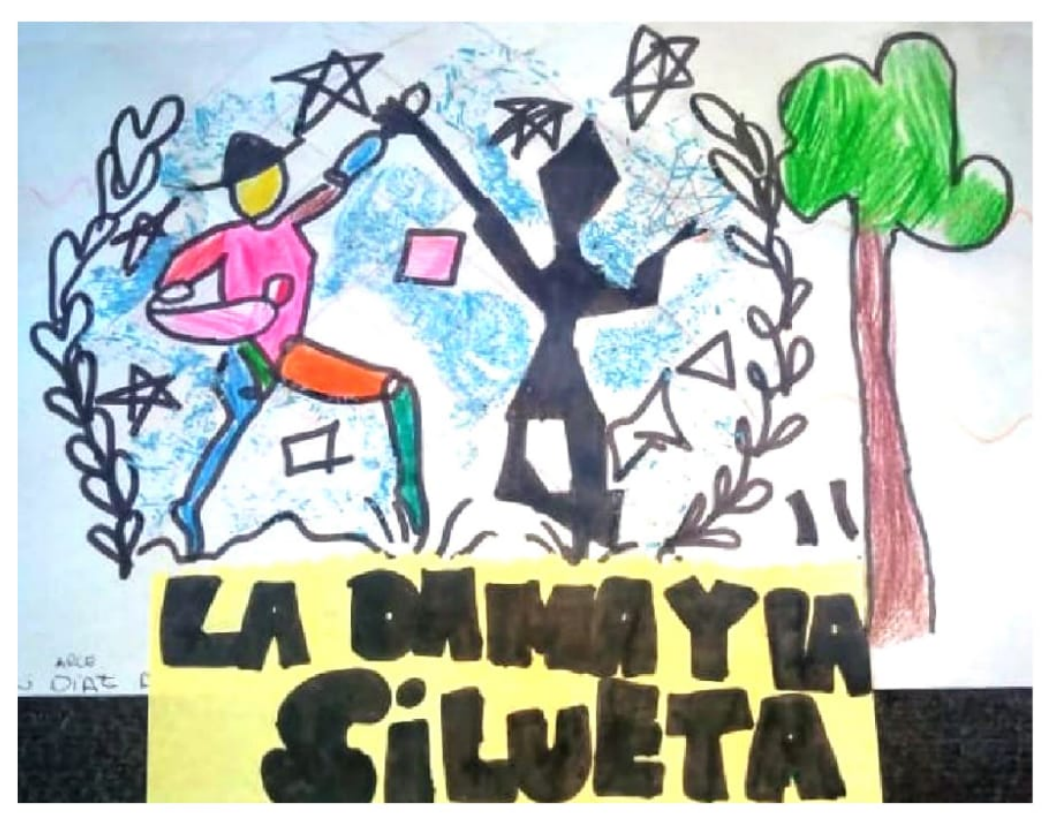

Joaco, "La dama y la silueta" 


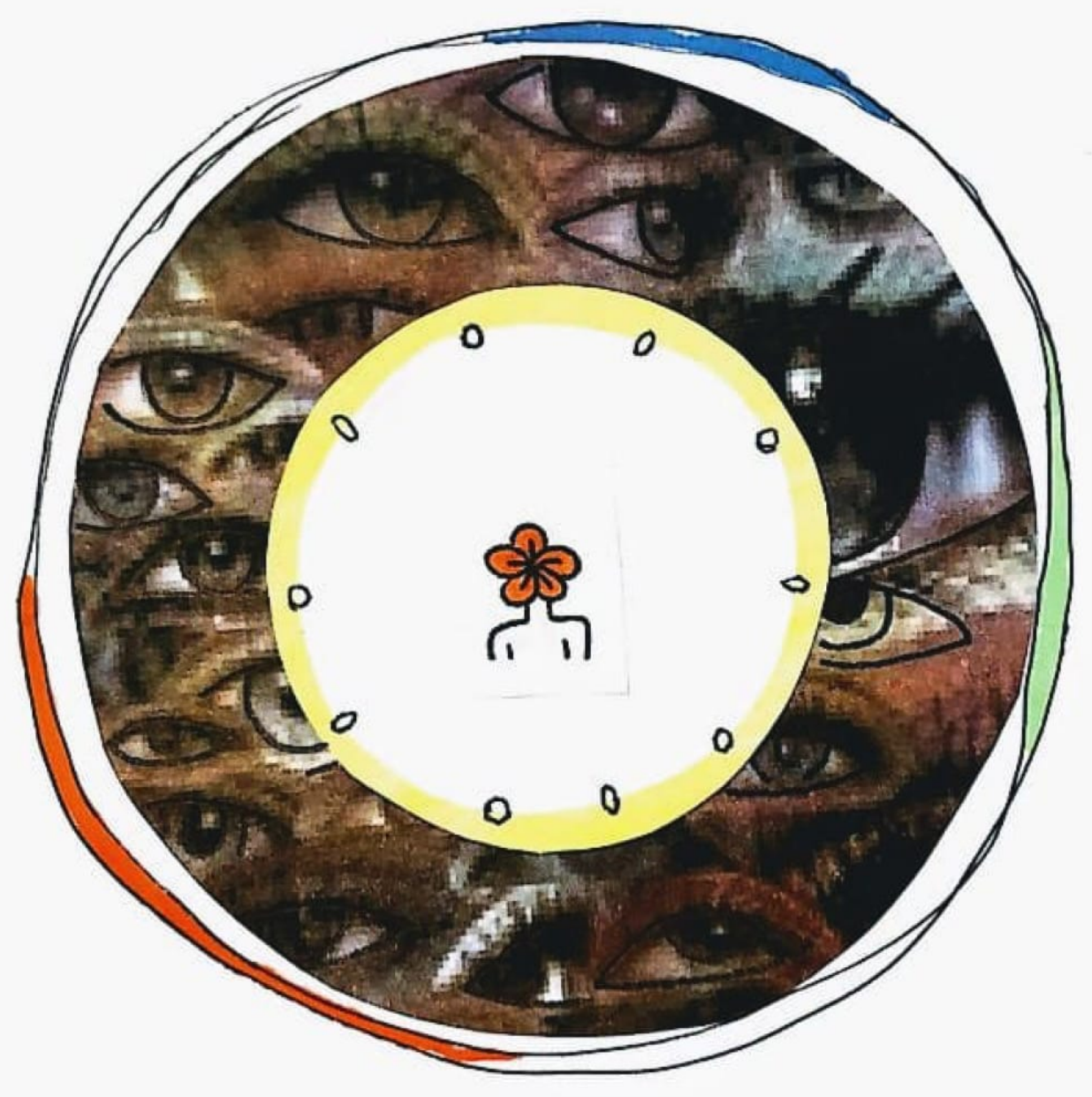

Morena, "Mirada al interior" 


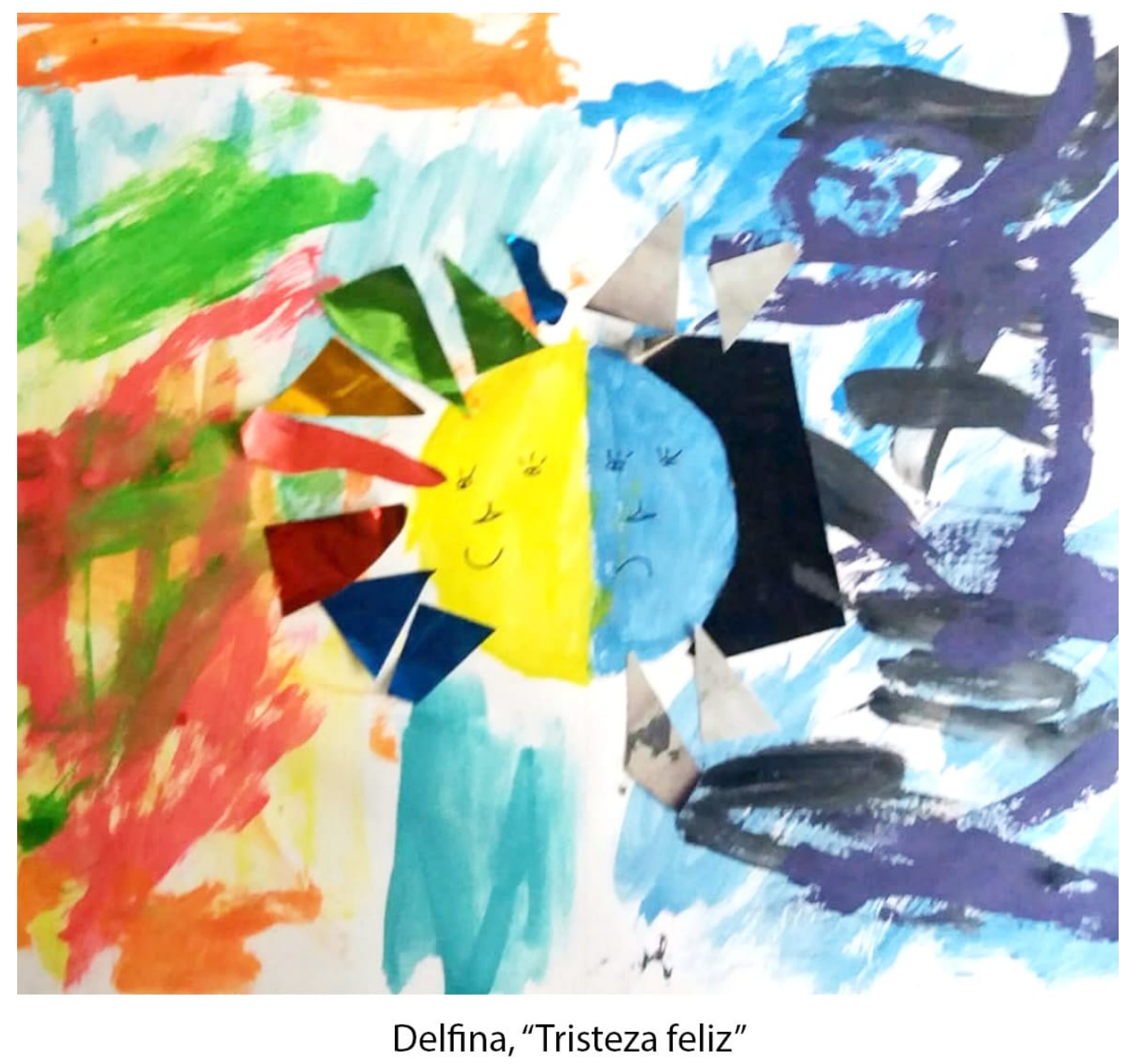




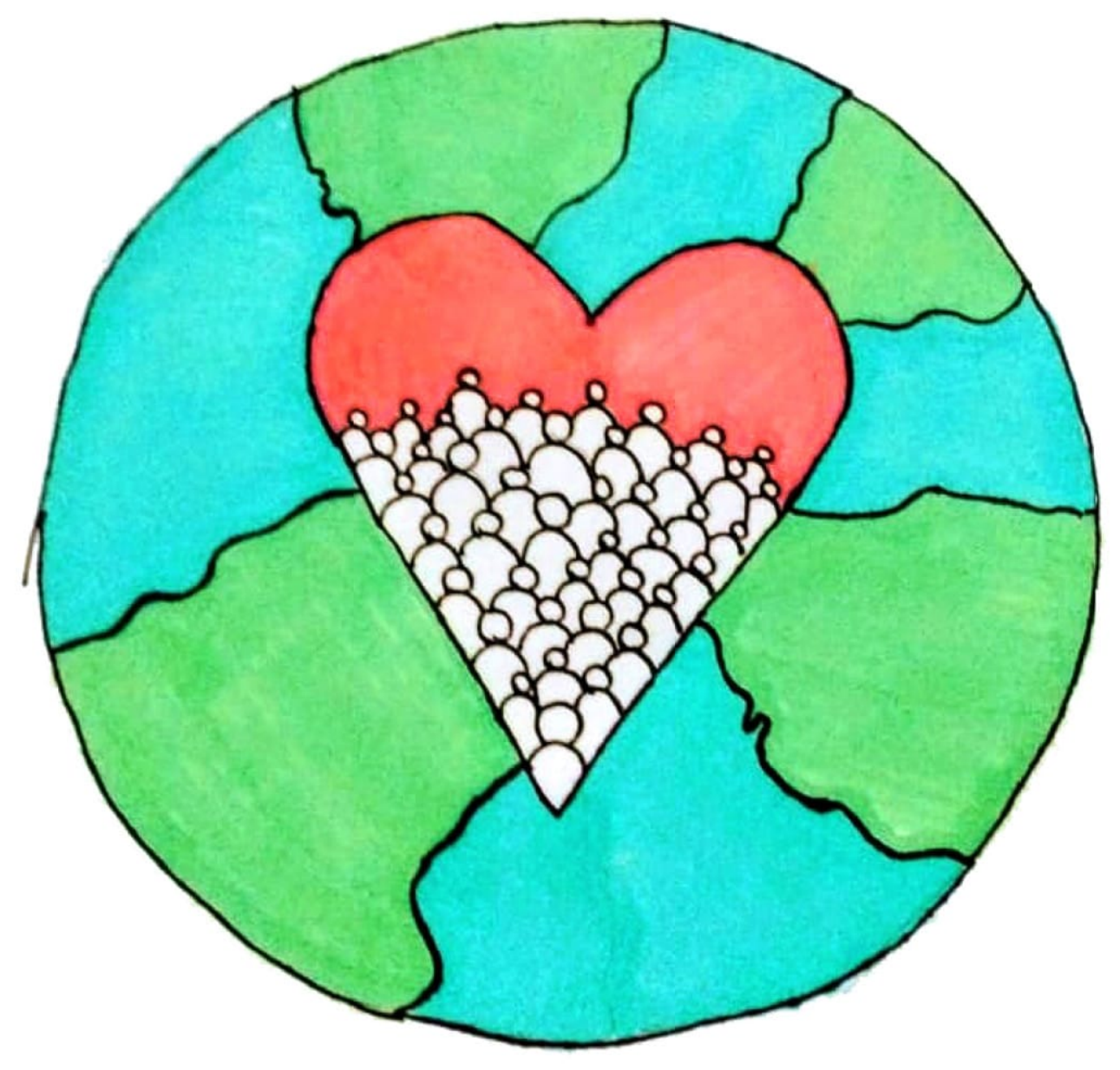

Reni, "\#cuarentenaunida" 


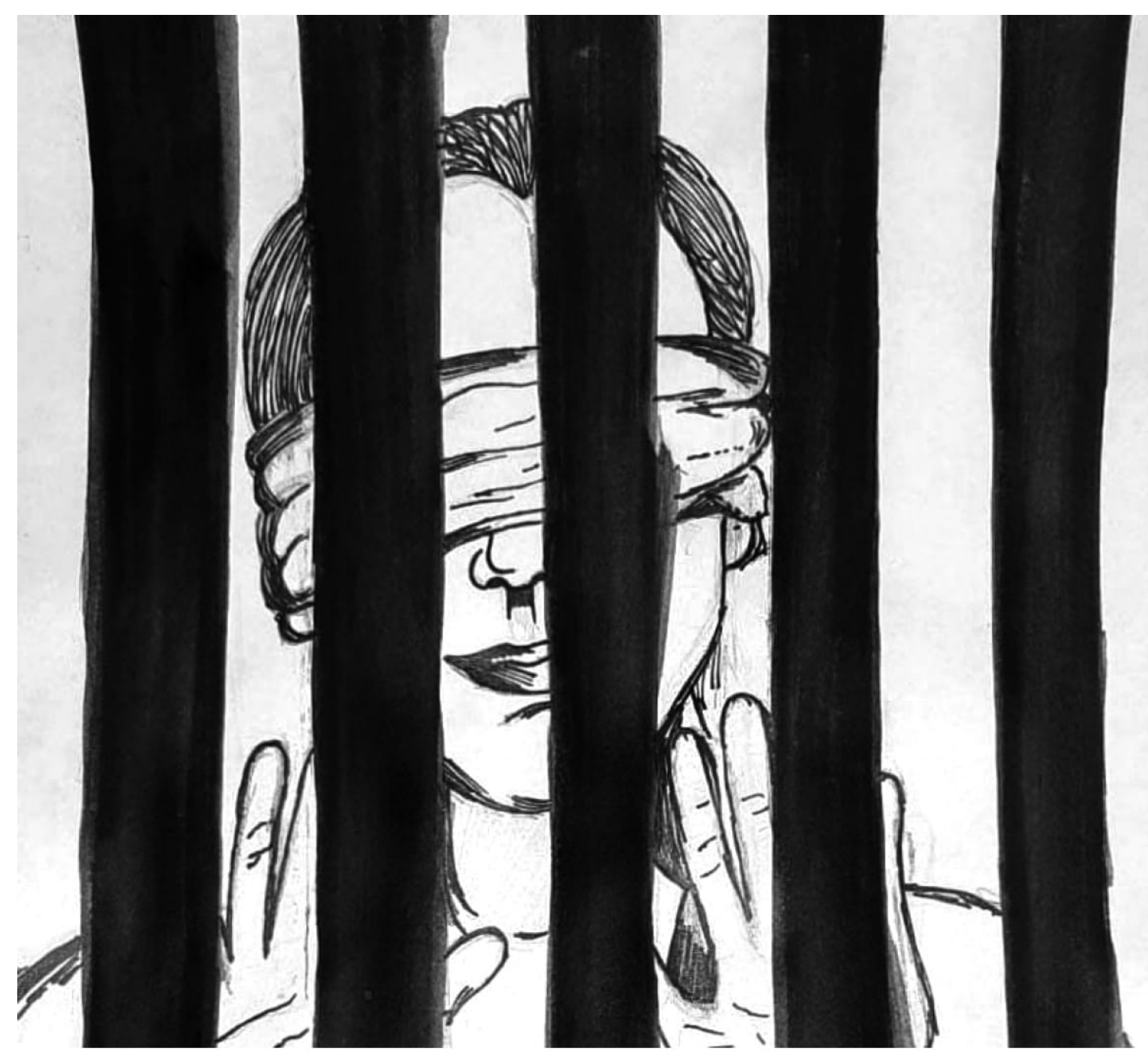

Trini, "Inevitable salvación” 


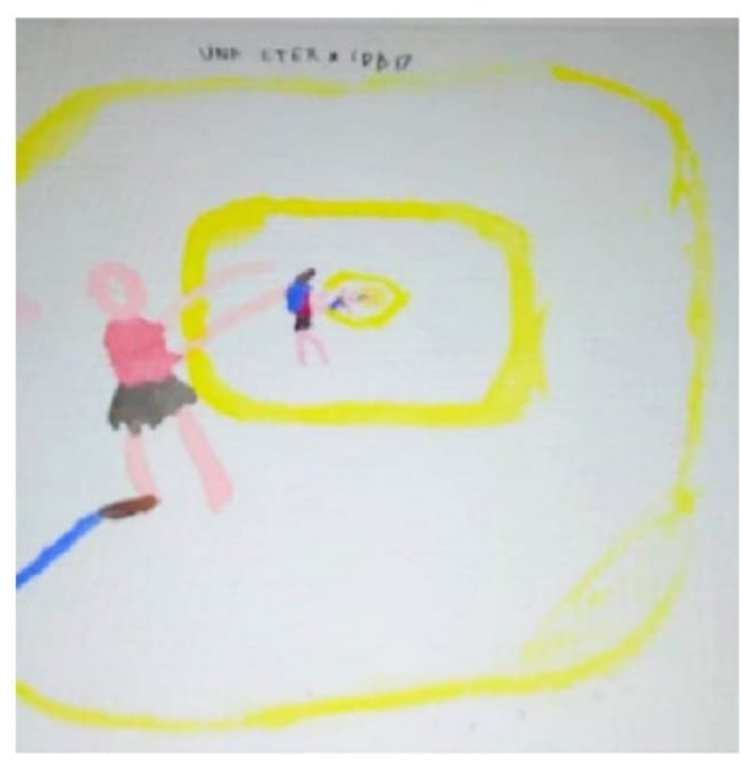

Isabel, "Una eternidad" 


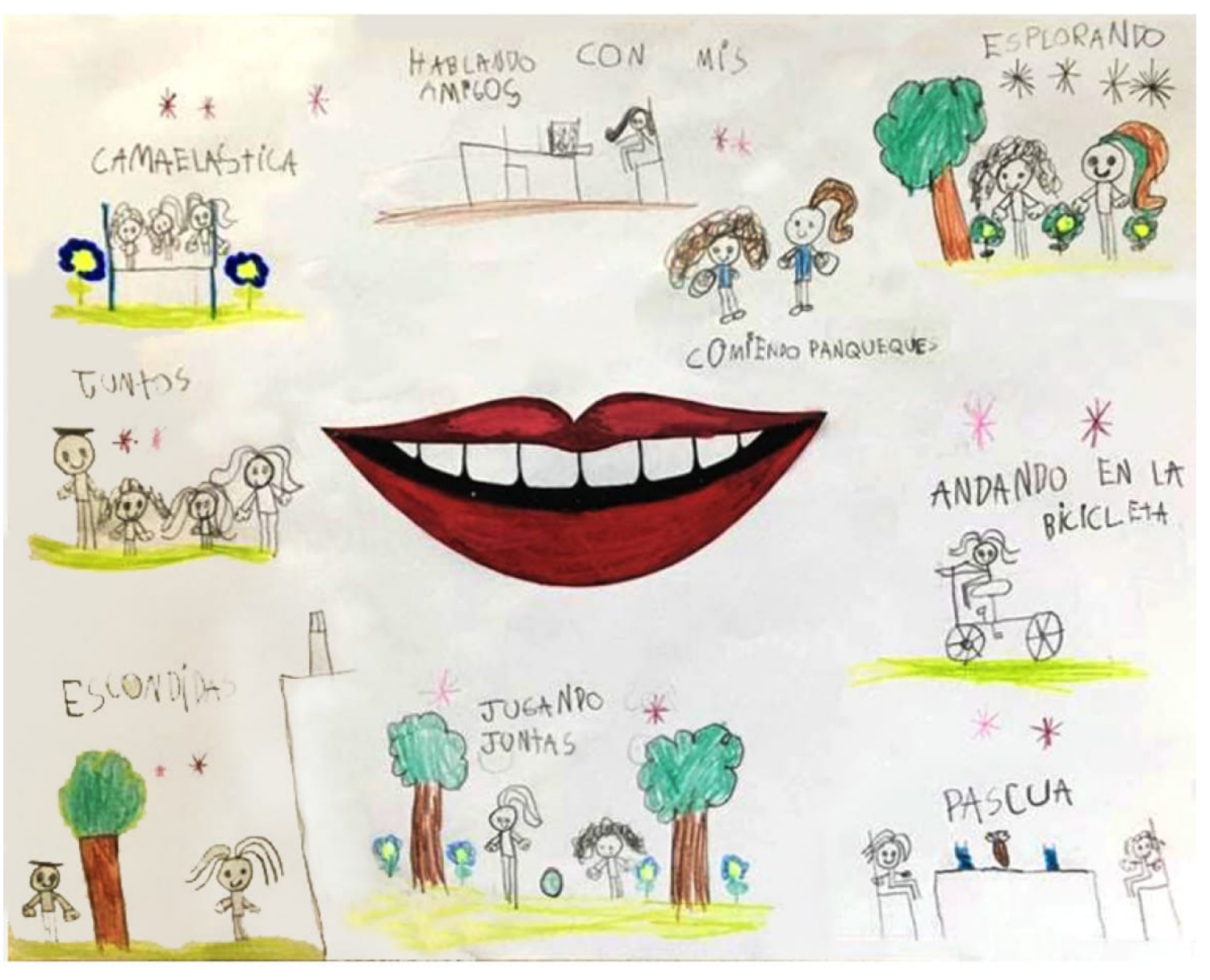

Clara, "Algunos días de alegría en cuarentena" 


\section{(c) ${ }_{\mathrm{BY}}$ (i) (2)}

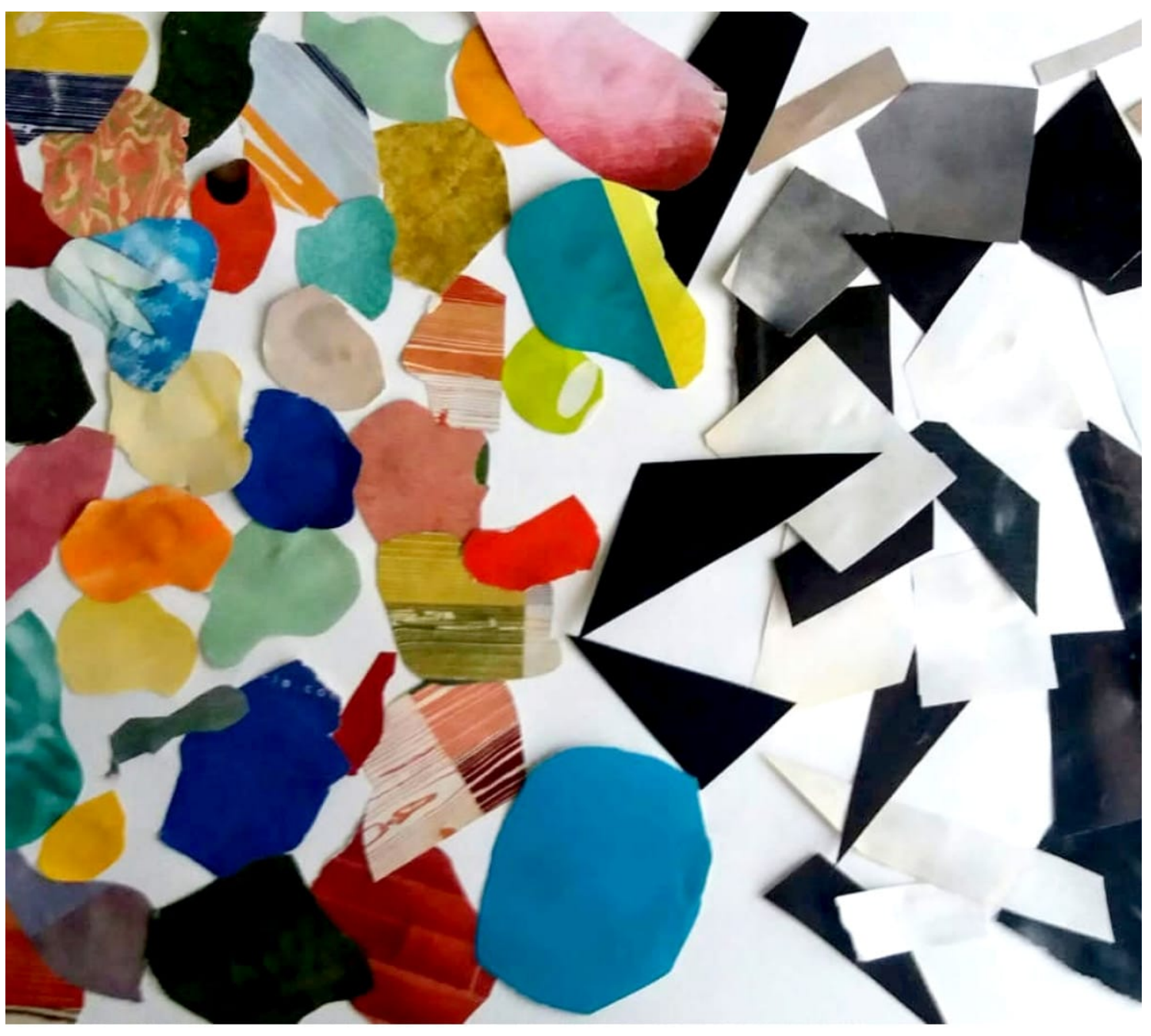

Pilar, "Diversión aburrida" 


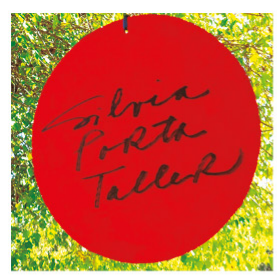

\section{Taller 2020 DESDE CASA \\ Lo que nos provoca \\ la Pandemia}

Esta semana la consigna fue expresar emociones y sentimientos de estos días de cuarentena, con los materiales que los chicos tuvieran en su casa.

Ana Majnaric, 5

Lara Landucci, 6

Augusto Firpo, 11

Lucía Camarda, 10

Bautista Pimentel, 9

Morena Nieves, 13

Carmela Garzia Otharán, 10

Ofelia Escudero, 7

Catalina Orsini, 5

Paula Miglio, 11

Clara Ribeiro Valerio, 6

Pilar Ferretti, 7

Delfina Ferretti, 5

Pilar Mazzuchi, 13

Flora Novaretto, 5

Renata Pérez Rojas, 11

Isabel Dabat, 11

Rosario Castaños Guerreiro, 10

Guadalupe Torres Parrella, 9

Tomás Camarda, 12

Joaquín Díaz Arce, 12

Trinidad Degenhardt, 15

Josefina Boero, 7

Vera Majnaric, 7

Justina Capdebarthe, 7

Virginia Rojas 


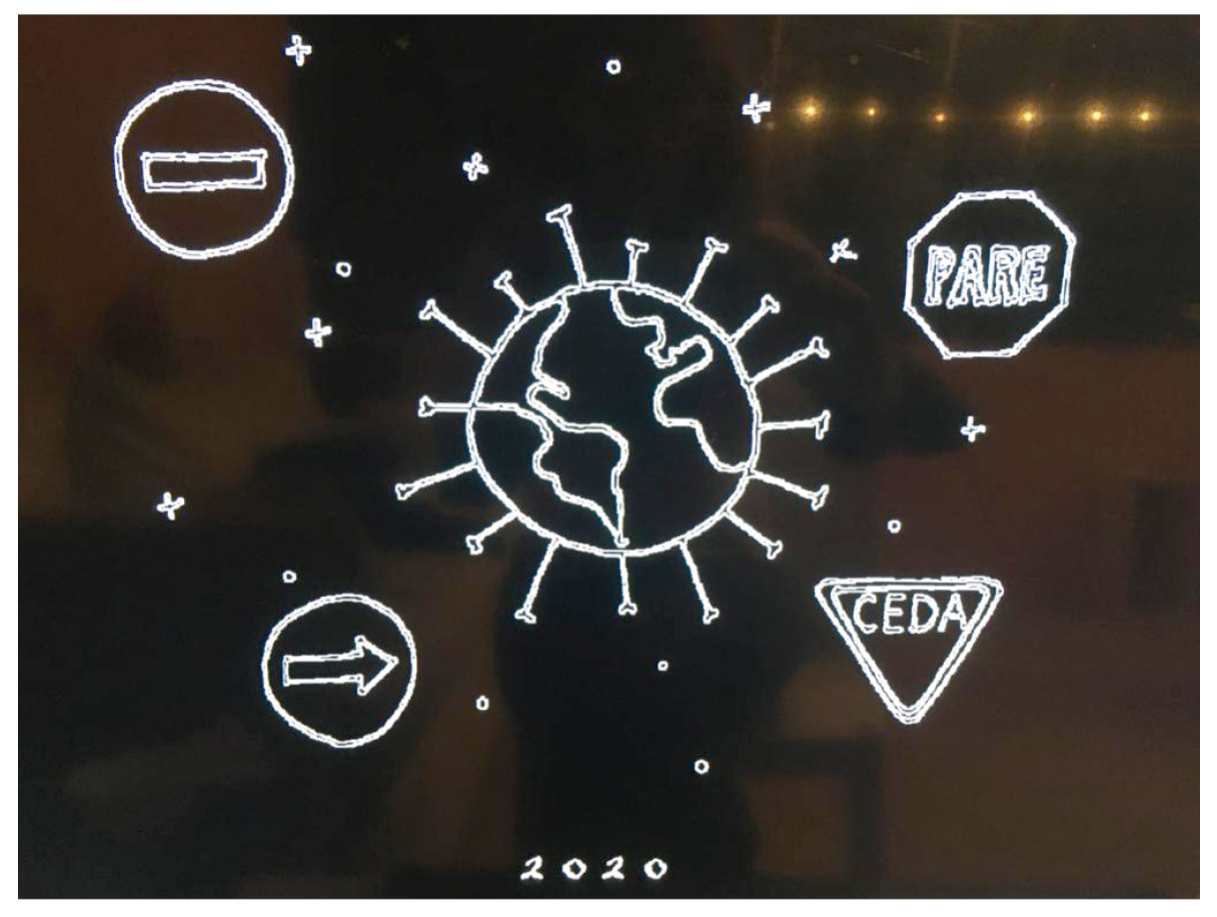

Virginia, "Señales" 


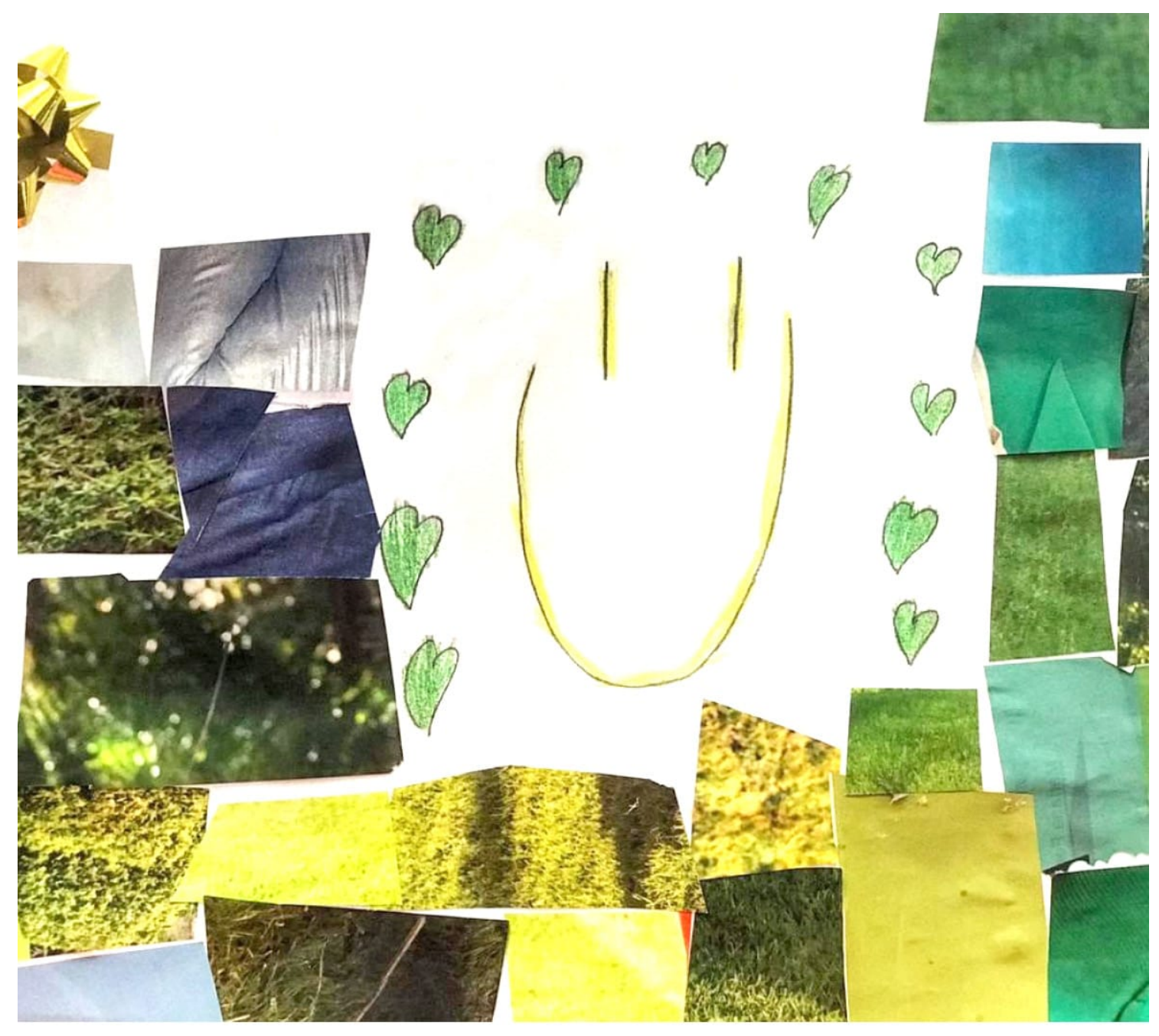

Ana, "La alegría" 


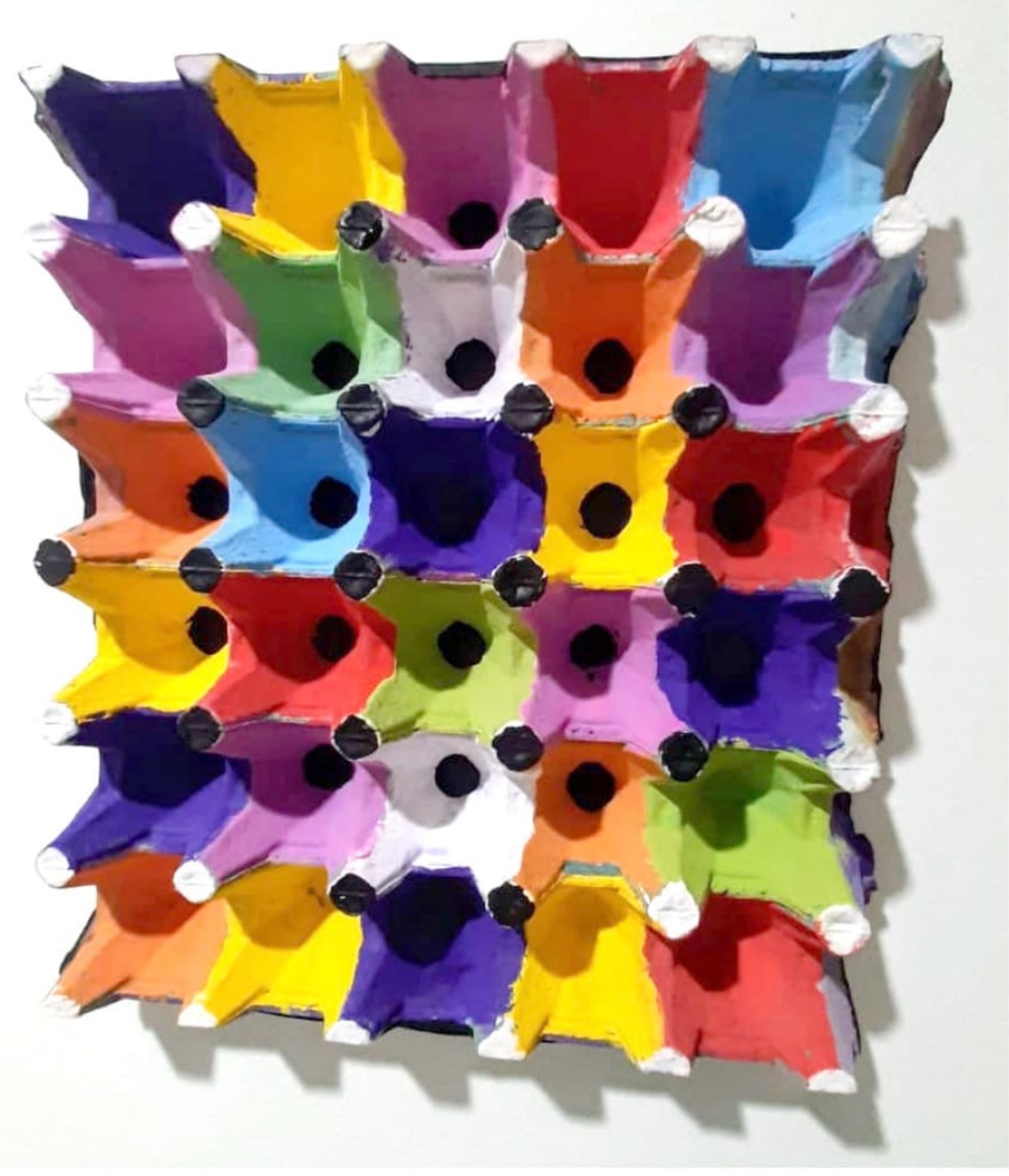

Rochi, "\#encierro" 


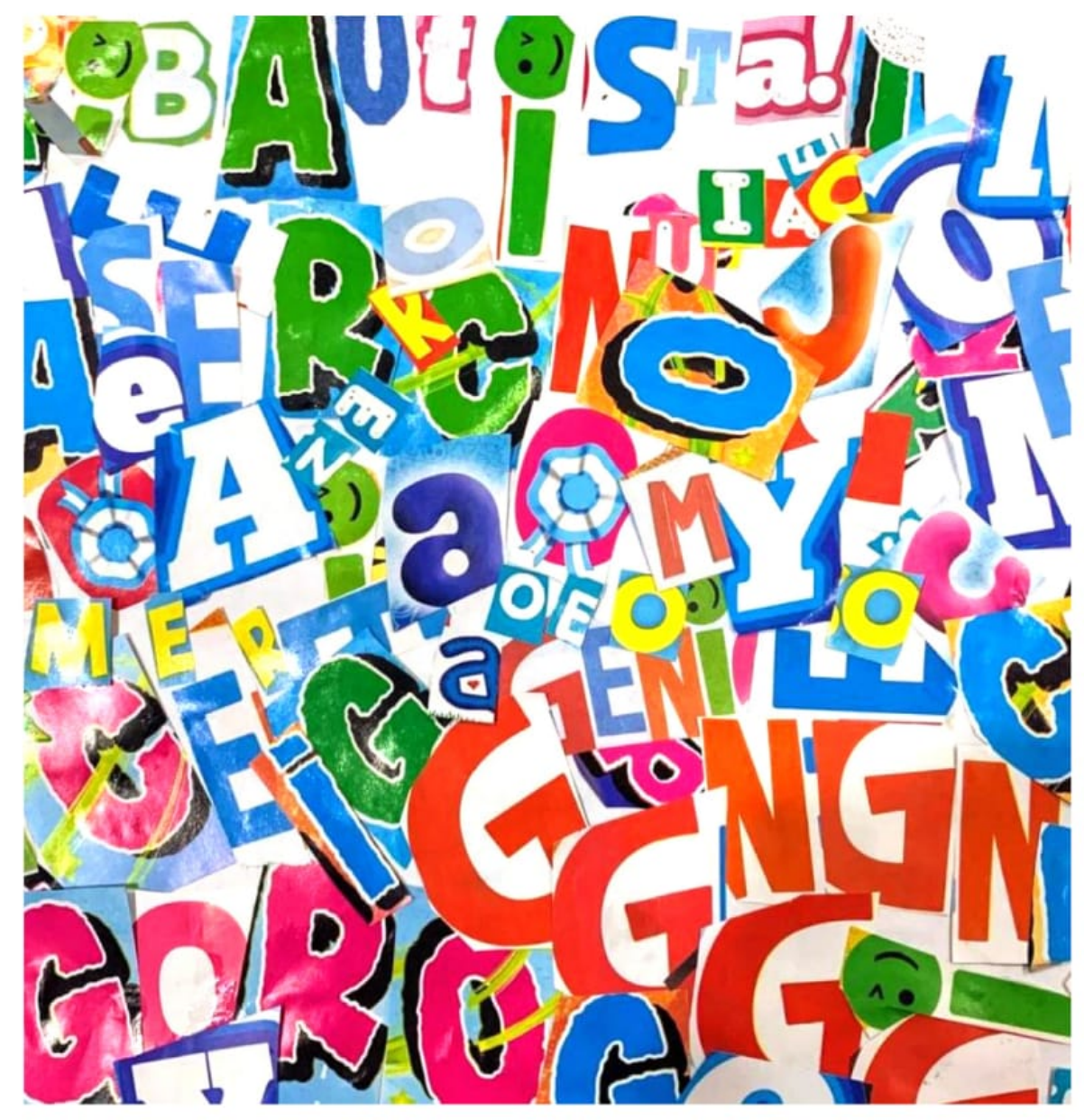

\section{Baucha, "Enletrados"}

